\begin{tabular}{|l||c|c||}
\hline Received 10.07.2021 & & JOTS \\
\hline Accepted 17.07.2021 & Research Article & $5 / 2$ \\
\hline \hline Published 24.07.2021 & & $2021: 253-295$ \\
\hline
\end{tabular}

\title{
Cüveynî̀nin Târîh-i Cihân-Güşâ Adlı Yazmasına Eklenen Sözlük
}

A Wordlist Added to the Manuscript of Tarìkh-i Jahān-gushā by Ata-Malik Juvayni

\author{
Youssef AZEMOUN* \\ Arizona/USA \\ E-mail:yusufguzin@gmail.com
}

Tarīkh-i Jahān-gushā by Ata-Malik Juvayni was written in the thirteenth century. A critical edition of this book was published at the beginning of the twentieth century in Europe. The same book was published recently in Tehran. This text is in Persian, but contains many Turkic and Mongolian words. The study of these words has recently become a linguistic issue in Iran. A number of people have studied the Turkish words in this text in an idiosyncratic folk etymological manner. This article deals with a brief critical review of these studies. Also treated here are some linguistic aspects of the Turkish words in the text and there is a translation of an extract from the book about the old Uygurs and an old inscription on a rock. A new manuscript of Tarikh-i Jahān-gusha from the Iranian National Parliament Library is then introduced. It is different from previous manuscripts in having as a supplement a glossary of Turkish and Mongolian words in the manuscript. The words in this glossary are copied, transcribed and their definitions translated from Persian into Turkish.

Key Words: Tarīkh-i Jahān-gushā, Turkish, Persian, Mongolian, manuscript.

\footnotetext{
ORCID ID: 0000-0001-5207-9046.
} 


\section{J(৫)}

\section{Giriş}

Alâüddîn Atâ Melik Cüveynî (1226-1283) önemli bir İslâm hukûku bilgini ve tarihçidir. Devlet yönetiminde de valilik gibi önemli görevler almıştır. Hülagu'nün Abbasîler ve İsmailîlerle savaşında onunla beraberdi. Elemût fethi sırasında İsmailîlerin kütüphanesinin yağmalanmasını engellemiştir. Sonra Bağdat ve Güney Beynennehren valisi olmuştur. Yaşadığı yerlerden topladığı bilgileri değerlendirerek 'Dünyayı Fethedenin Tarihi' anlamına gelen üç ciltlik Tarih-i Cihan-güşâ kitabını yazmıştır. Bu kitapta Moğollar ve İlhanıların, Harzemşahlıların ve İsmailîlerin tarihleri anlatılıyor. Cüveyni, fikıh, kelâm ve hadîs gibi konularda birçok kitap yazmışsa da Tarih-i Cihan-güşa adlı eseriyle ün kazanmıştır. Cüveynî’nin Farsça yazdığı bu eserini Mirza Muhammed Kazvînî bazı nüshaları karşılaştırarak 1912, 1916 ve 1931 yıllarında üç cilt hâlinde yayımlamıştır. Kazvînî, Cüveynî ve eseri hakkında uzun ve ayrıntılı mukaddime de yazmıştır. Tarih-i Cihan-güşâ en son 1387'de [1968] Tahran'da Sâzemân-e Çâp ve Enteşârât tarafından basılmıştır. Bu kitap Mürsel Öztürk'ün çevirisiyle Kültür Bakanlığı tarafından önce 1988 'de üç cilt hâlinde sonra da 1998'de tek cilt hâlinde yayımlanmıştır.

Son zamanlarda, İran'da Farsça edebî eserlerde, özellikle de Tarih-i Cihangüşa'da bulunan Türkçe ve Moğolca sözler üzerinde makale ve kitaplar yayımlanıyor. Bu yayınlarda daha çok Türkçe sözlerin anlamı ve etimolojisi üzerinde duruluyor. Türkçe sözler incelenirken daha çok Azerbaycan Türkçesi açısından değerlendiriliyor. Meselâ, yakın zamanda İran'da basılan Tahlîl-e

Sāhtāâi ve Maāanî̀ye Berhî Aclām-e Torkî-ye Tārîh-e Cahān-guşā-ye Cuveynî [Cüveynînin Târîh-1 Cihân-güşâ adlı eserindeki Türkçe Kelimelerin Yapısal ve Semantik Analizi] adlı makalede Cüveynî'de geçen bazı Türkçe sözler açıklanmıştır. Bu yazıda Farsçada Sebok Tekin olarak bilinen Gazneli Sultan Mahmut'un adının aslının su bay tegin ya da tekin olduğu iddia ediliyor. Halbuki bu ad aslında Sepük Tigin'dir. Sepük de Eski Türkçede 'düzenli, tertipli, mücehhez, hazırlıklı' demektir. Ya da ötkin sözünün anlamının 'tesir edici' olduğu açılanıyor ve od kimin'den türemiş olabileceği söyleniyor. Bir kuşla ilgili olan alaca sözü alıcı ile ilişkilendiriliyor ve 'yırtıcı kuş' anlamına geldiği açıklanıyor. ‘Güzel' anlamına gelen gökce de yeşil renkle ilgilendiriliyor. Bu, İran'da yaygın bir 
eğilimdir. İran'da basılan Senglah Çağatayca sözlüğündeki sözlerin çoğu da Azerbaycan Türkçesine göre okunmuştur.

Türkiye'de de Cüveynî'de geçen Türk dili ve kültürüyle ilgili unsurlar Ercilasun'un Türk Dili dergisinde basılan Atâ Melik Cüveynî Neler Gördü, Neler Duydu? adlı makalesinde irdelenmiştir (2020: 4-9). Ercilasun, bu makalede Uygurların türeyiş efsanesini açılayan bölüm üzerinde durmuş ve bu efsaneyi çok yönlü olarak incelemiştir. Ayrıca, metinde anlatılan yazıtın üzerinde de durmuştur. Ercilasun'un makalesini okumadan önce ben Tarih-i Cihan-güşẩnın Türkçe çevirisi elimde olmadığı için Farsçasından okumuştum ve Ercilasun'un değerlendirdiği konular benim de dikkatimi çekmişti ve not almıştım. Tekrarlanmasının yararlı olabileceğini düşünerek ilgimi çektiği için Farsçadan çevirdiğim bölümleri makalemde açıklayacağım. Farsça Cüveynî tarihini okurken Eski Türklerle ilgili çok değerli bilgiler olduğunu fark ettim. Tarihin Farsça metninde istinsah hataları olduğunu ve Türkçe kelimeler düzeltilirken de hatalar yapılmış olduğunu gördüm. 0 yüzden bazı yerler yanlış anlaşılabilir ya da anlaşılmayabilir. 148. sayfada, Uygurların Kendi Dilinden Uygur Şehirleri ve İdi Kut’un Nesebi Üzerine başlı̆̆ altında yazılan bölümü okurken de cümle düşüklükleri olduğunu fark ettim ve metni Türkçeye şöyle çevirdim:

Onlarla ilgili durum kayda geçirildiğinde onların kitaplarında yazılan düşünce ve dinî inançları hakkında kısaca bilgi, şaşırtmak için değil, onaylamak için yazıldı. Uygurların benimsediği düşünceye göre onların ortaya çıkışları Orkun ${ }^{1}$ nehrinin kıyısında olmuştur. Orkun'un kaynağı Karakorum denen dağdandır. Burada Kaan zamanında bina edilen şehrin adına da Karakorum derler. Bu dağdan otuz nehir su alır. Her nehrin kıyısında ayrı bir kavim yaşardı. Orkun'da da Uygurlar iki topluluktu. Bunların toplulukları çoğalınca başka kavimlerin de onayı ile kendi aralarından bir emîr tayin ettiler ve ona itaat ettiler. Beş yüz yıl boyunca (s. 149) böyle yaşadılar ta ki Buku Han'ın dönemi gelip çattı. Halk arasında Buku Han'ın Efrasiyab olduğu yaygındı. ${ }^{2}$ ve bir kuyu yıkıntısı var ve büyük bir kaya (var) dağda, Karakorum'un kenarında, Bîjen Kuyusu olduğu söyleniyor. ${ }^{3}$ Bu nehrin kıyısında, onun adı da Ordu Balıg'dır ve şimdi ona Mavu Balığ derler. (Padişah) dergâhının yıkıntısının dışında, kalenin hizasında üzerine satırlar kazılmış taşlar atılmıştı. Biz bunlara baktık. Kaan'ın devletinin zamanında bu kayaların altını açtılar, bir kuyu buldular ve kuyuda üzerine yazı

\footnotetext{
Dipnotta Org̉un yazılmıştır.

Burada düşüklük olmuş, zira konu değişiyor.

Burada düşüklük olmuş.
} 
kazılmış büyük bir kaya buldular. Yazının çözülmesi için buyruk verildi. Kimse onu okuyamadı. Hıtay'dan ${ }^{4}$ denen bir kavmi getirdiler. $O$ cemaatin yazısıymış.

Şimdi de Balasagun şehrinin adının nasıl Ġuz Balig (Oğuz şehri) olduğunu anlatan bölümün çevirisini veriyorum:

\begin{abstract}
Buku Han rüyasında beyaz giysili ve beyaz bastonlu yaşlı bir adam gördü. Bu adam elindeki çamfıstığı şeklinde olan yeşil taşı ona verdi ve "Eğer bu taşı koruyabilirsen dünyanın dört bir yanı senin buyruğunu temsil eden bayrağın gölgesi altında olur" dedi. Veziri de buna benzer rüya görmüş. Sabahleyin ordularıyla yola koyuldular. Türkistan hudutlarına vardıklarında bol yeşillikli ve sulu kırsal bir alan gördüler. Huzur veren bu yere yerleştiler. (Buku Han) burada Balasagun şehrini bina etti. Şimdi ona Ġuz Bahı̀ diyorlar. On iki yıl içinde (o civardaki) bütün bölgeleri fethettiler ve isyan edecek kimse bırakmadılar. Sonra insan görünüşlü hayvanların yaşadığı bir yeri gördüler. Oranın ötesinde iskân edilen bir yer görmedikleri için döndüler.
\end{abstract}

Bu makalenin amacı İran'da Türkçe ile ilgili yazıların değerlendirilmesi değil, Cüveynî tarihindeki bazı ilginç sözleri gözden geçirmek ve onlar hakkında notlar düşmek hem de Cüveynînnin Târîh-i Cihân-güşâa adlı eserinin eski bir elyazmasına eklenen bir sözlüğü tanıtmaktır. Bu yazma eser İran'ın Meclis-e Şûrâ-ye Mellî kütüphanesinde, Kitab-e Tarîh-e Cihān-güşâ-ye Cüveynî bâ Ferheng-e Lugât adıyla ve hüviyeti, "Müellif: Ata Melik Cüveynî, Kutu numarası 9311" şeklinde kayda geçirilmiştir. Tarih kitabının son sayfasında sözlüğün birinci sayfasıyla birlikte basılmış. Cüveynî tarihinin yazma nüshasının son sayfasında eserin Muhammed bin Hüseyin tarafından Hicrî kamerî 1317'de tamamlanmış olduğu yazılmıştır. 1365'te de Cafer Sultan el-Karânînin kütüphanesinin mührü basılmış, daha sonraki sayfada da aynı şahsın hattıyla yazmanın sözlük bölümünün başlangıcı yerleştirilmiştir. Bu makale daha çok bu sözlük üzerinde odaklanacaktır, ancak daha önce Cüveynî tarihindeki ilginç görünen bazı Türkçe sözlerin tanıtımı yapılacaktır. Zaten sözlük bölümünde çok sayıda Türkçe sözlerin açılanması var.

Üç ciltlik Târîh-i Cihân-güşầnın Farça metnini gözden geçirdim. Çok sayıda Türkçe ve Moğolca sözler var. Bunların çoğu yarlig, al tamǵa gibi bilinen sözler. Bunlardan ilginç bulduğum ve açıklanması gereken bazı sözler üzerinde durmak istedim. Meselâ bugün Çimen-i Sultâniye denen yerin adı Moğolcada koňur öleň

\footnotetext{
4 Dipnotta bir nüshada beyaz, üç nüshada da Kamaan قامان . Kamân, kam 'şaman filozofu ve müneccimi' sözünün çoğuludur. Aşağıdaki sözlükte قام maddesinde açıklama var: kāmān, kām’ın çoğulu. Burada bilginler topluluğundan söz edilmiş olabilir.
} 


\section{ग(৫)}

imiş; Türkmencede koňur 'kahve rengi', öleň 'çayırlı, çimenli yer demek. Mağtımgulı'da şöyle bir beyit var: îller bâr diňli diňli // Sowuk suwli ter öleňli. Türkmen halk edebiyatında, düğünde kız tarafından bir kadının söylediği yâr yâr nakaratlı bir türküye de öleň denir (Azmun, 2020: 666). Geçmiş olayların kaydedildiği tomara ötük denmesi ilginç.

Metinde Güyük Han'ın zevcesinin adı Kaymış olarak geçiyor ve aslında Oğul Kaymış olduğu hakkında not düşürülmüştür. Bu adın sahibi oğlan beklenirken doğmuş olmalı. Oğlan beklenirken doğan kızlara bugün Türkmenlerde de Oğul ile başlayan ad veriliyor: Oğulcan, Oğulgül, Oğulbibi, Oğulgerek gibi. Türkmenlerde ayrıca Dursun da kız adıdır. Farsçada bu ad 'kız yeter artık' anlamında Duhterbes'tir. Kızlara oğul adı verilmesi bir Oğuz geleneği olmalı. Sevinç adı Sevinç Han örneğinde erkek adı. Bu ad Türkmenlerde Söyünç şeklinde var. Sunkar Aşkar adındaki birinci söz ‘şahin, doğan' demek; aşkar da Arapçada 'kızıl saçlı adam' ve 'sarıya çalan kırmızı renk' demek. İran ve Türkmenistan sınırındaki Etrek nehrinin adı da aynı anlamda. Bu, nehrin su altındaki toprağının rengiyle ilgili. O yüzden bu nehre Kızıl Etrek de denir. Bunu bazıları bolşevistik bir ad olarak algiliyorlar.

Şütür katar kerden ‘deveyi katarlamak, sıralamak' anlamına gelir. İngilizcede sıralanmış deveye train of camels deniyor. Bunun bire bire anlamı 'deve treni'. 0 yüzden Farsçada trene kațār deniyor ve gațār şeklinde telaffuz ediliyor. Feraye türküsünde Türkmen kızı katarlamış mayayı deniyor. Buradaki maya, buğranın dişisi, sarışın devedir, gelini, bazen de mevtayı taşır. Bu devenin kutsal bir hayvan olarak kabul edilmesiyle ilgilidir. O yüzden deve yününden yorgan yapılır, ama tepelendiği için döşek yapılmaz.

Bu metinde Tacik sözü Tâzik şeklinde yazılır. Eski Türkçede bu söz Tezik'tir. Farsçada Türkçe kelimelerdeki açık /e/ sesi elif ile yazılır. O yüzden tezik de tāzik olmuştur, tıpkı Türkçe külek > kûlâk, Türkmen > Türkmân, Moğolca kekül'ün de kâkül oluşu gibi. 'Saldırgan' anlamına gelen tāzî hem tazıyı anlatır hem de Arapları.

${ }^{c}$ Avret > avrat sözünün Farsçadan Türkçeye geçtiğini biliyordum ama Farsçada ne zaman kullanılmaya başlandığını bilmiyordum. Tarih-i Cihan-güş̧â'da 'avret sözü 'kadın' anlamında kullanılıyor. Halbuki Arapçadaki anlamı 'çıplaklık'tır. Bu eser XIII. yüzyılda yazılmıştır. O yüzden bu kavramın XII-XIII. 


\section{J(৫)}

yüzyıllarda yaygınlaştığını düşünebiliriz. 'Avret sözünü 1298'de yazılan Yusufve Zuleyhâ mesnevisinde er ü cavret var. Bu söz bugün Türkçede avrat olmuştur ve Türkçe uragut'tan türeyen arvat ile karışmıştır. XIII. yüzyıl Kazvinli şair ve yazar Ubeyd-i Zâkânî'de ve Hutsma da arvat kelimesi ayın ile değil elif ile şeklinde yazılıyor. Bugün Türkmencede ve Azerbaycan Türkçesinde arvat/arvad sözü kullaniliyor.

Cüveynî'de merdîne 'erkek' cinsi, 'avretîne de 'kadın cinsi' demek. 'Boynuzdaş' anlamında gelen hem-şāh bu metinde 'baldız' anlamında kullanılıyor ve birebir anlamı 'boynuzdaş' olan hem-sāhn, Türkçe boynuzlu'nun mecazî anlamını akla getiriyor. Farsça hem ön ekinin Türkçe karşıllı̆ı \{+dAş\} ekidir. Farsçada şikem 'karın' demek ve 'karındaş' anlamına gelen hem-şikem 'ikiz' demektir. Buna göre karındaş > kardaş > kardeş sözünün en eski anlamı 'ikiz' olabilir. Zira Eski Türkçede kardeş için toǵmış, Türkmencede de doǵan sözü kullanılıyor. Türkmencede garındaş da 'akraba' anlamına geliyor.

Mengüberti'nin adı ş şكبرنى sieklinde yazılmış. Belki bu ad aslında şeklinde yazılmış, fakat $<$ t> harfinin iki noktası üst üst gelip bir nokta gibi görünmüş olabilir. Böyle durumlar elyazma metinlerde olağandır. Son zamanlara kadar bu ad Farsçada Monkebernî şeklinde okunuyordu. Bu ad 'Tanrı verdi' anlamına gelir. Bu hükümdarın Farsçadaki diğer adı da Celâleddîn Hudâdâd (Allah verdi)'dır. Taňrıberdi, Allberdi ve Hudayberdi bügün Türkmenlerin yaygın olarak kullandığı adlardır. Türkmenistan'da da bu söz Meňburnı şeklinde okunuyor ve Celaleddin Harezmşah'ın burnunda ben olduğu için böyle dendiğine inanılıyor. Metinde Harezm için de "Bu nahiyenin halkı ona Cürcâniye'der ve yerli halk ona Ürgenc derler" deniyor. Bu şehrin asıl adı Gürgân'dır ve İran'da, Türkmen Sahra'da Gürgen nehrinin kıyısında yerleşen eski bir şehirdir. Araplar buna Cürcân derler. Benzer bir adla bugün Türkmenistan'ın kuzey sınırında yerleşen şehre de Gürgân Gird denmiş. Gird 'yuvarlak' demek ve eski şehirler yuvarlak kale içinde yerleştiği için bu söz Farsçada 'şehir' anlamına geliyor. Bugün İran'da Sûsengird şehri var. Arapçada /g/ sesi /c/ olduğu için gird, cird olmuş. Kuzeydeki şehrin adı da önce Gürgâncird, sonra da kısalarak Gürgânc olmuş, daha sonra da bu ad Türkmencede Ürgenç olmuştur.

Aykak, Eski Türkçede 'dedikoducu' anlamına gelir. Metinde yanlış olarak uyḳak şseklinde yazılmıştır: Mã uyḳak-ı yalavacîm, mâ râ be-çe günâh girifteîd? 
"Biz peygamberin/önderimizin dedikoducusuyuz, günahımız ne ki bizi burada tutuyorsunuz?”. Aynı yerde şöyle bir satır var: Dehân güşâde şakāyıl çü merdüm-i uykak "Şakayık çiçeği dedikoducu insanlar gibi ağzını açmış". Bu metinde koruyucuya da țurkak deniyor. Bu ad 'beklemek' anlamına gelen tur- fiilinden \{kAk\} ekiyle yapılmıștır ve ‘sürekli duran, bekleyen' anlamına gelir. Daha sonra \{Ak\} şekline dönüşen ekle yapılan kavramlarda da bir süreklilik ifadesi vardır: kaçak 'sürekli kaçan', korkak 'hep korkan', ürkek 'hep ürken' gibi. Türkmencede de sürekli altını kirleten çocuğa sıçak derler. Metinde geçen çök zeden 'saygı göstererek diz çökmek’ anlamına gelir. Bu birleşik fiildeki zeden Türkçe uryardımcı fiilinin bire bir çevirisidir: gep zeden > gep ur- > gepir- 'konuşmak', cî̀g zeden > çı ur- > çı̆̆ır- örneklerinde olduğu gibi.

Cüveynî̀nin Târîh-i Cihân-güşâ adlı eserinde çok sayıda Türkçe sözler var. Hepsini incelemek elbette büyük bir iş. Basılan kitaplar pek güvenilir değil. Bu kitaplar birkaç yazma nüshanın karşılaştııılmasıyla hazırlanmış, ama yeterli değil. Birkaç yazma üzerinde tarihçilerle birlikte çalışılırsa çok yararlı sonuç elde edilebileceğini düşünüyorum.

Şimdi yukarıda belirtilen Târîh-i Cihân-güşâ yazma metnine ilâve edilen ve metinde geçen "Çağatayca" sözlerin anlamları Farsça açıklanan anlamlarının transkripsiyonunu ve Türkçeye çevirisini aşağıda veriyorum. Bu sözlükte Türkçe kavramlardan çok şahıs atları ve yer adları var. Bazı sözlerde belli harflerin harekeleri açıklanmıştır. Bunlar sözlerin doğru okunmasını kolaylaştırıyor. Telaffuzu konusunda kuşkulu olduğum sözlerin yanında bir soru işareti koydum. Bazı sözlerin anlam açıklanmasında hatalar var, onları da not düşerek açıladım.

Sözlüğün çeviri ve transkripsiyonuna başlamadan Farsça metinlerin okunuş türleri hakkında bir kısa bir açıklama yapmak istiyorum:

Bugün, İran Farsçası (Fars.), Tacikçe (Tac.) ve Türkiyede Avrupa transkripsiyonuna bakılarak Darî, hattâ Dârî olarak bilinen Afganistan Farsçası ya da açı /e/ ile Därî şeklinde telaffuz edilen Derî (Der.) ve Osmanlıca Farsçası (Osm. = Osmanlı Türkçesi) olmak üzere dört çeşit Farsça vardır. Bunlar temelde bir ise de başka farklılıklar yanında fonetik bakımından da farklılık gösterebilirler. Bu fonetik olay genellikle belli seslerin telaffuzunda aşağıdaki gibi ortaya çıkar: 


\section{0}

1. Tac. ve Der.'de /u/ Fars.'da bazen /o/, Osm.'da ise genellikle / ̈̈/ olur. Meselâ Tac. ve Der'de bulbul > Fars. bolbol, Osm. (Türkçe) bülbül. Tac. ve Der. Guftä de Fars.'da gofte şeklinde telaffuz edilir, Osm.'da da güfte olur. İki (2) sayısının karşıllı̆ı olan Osm.'daki dü, Tac. ve Der.'de du, Fars.'da da do şeklinde söylenir. Türk kelimesi Tac. ve Der.'de Turk iken İran Farsçasında Tork olmuştur. Tacikçede, Özbekçede olduğu gibi uzun /ā/ uzun /ō/ sesine yakın bir sesle telaffuz ediliyor.

2. Tac., Der. ve Osm.'da /i/ sesi Fars.'da /e/ oluyor: dil > del 'gönül', gil ya da kil > gel 'çamur' gibi; Der., Tac. ve Osm.'da Farsça datif eki olan bi- Farsçada beşeklinde telaffuz edilir: bi-män > be-män 'bana' örneğinde olduğu gibi. Tac., Der. ve Osm.'daki bismiillāh Fars.'da besmellāh oluyor. Tac. ve Der.'de uzun kapalı /ê/ telaffuz edilen ses, Farsçada /î/ oluyor, Osm.'da kâh /î/ da /ê/ ya da /ey/ oluyor: Türkçe \{+sIz\} ekinin karşılığı olan Fars. bî̀+ eki Tac. ve Der.'de bêे+, Osm.'da da yukarıda belirtildiği gibi bê+ ya da bey+ oluyor. Meselâ Farsça bîkār 'işsiz' Tac. ve Der.'de bêkār oluyor. Bu söz Azerbaycan Türkçesinde bekâr oluyor ve birçok yerde yanlış anlaşllıyor. Farsça bînämāz Tac. ve Der.'de bênämaz, Osm.'da beynamāz oluyor. Farsça şîr 'arslan' Tac. ve Der.'de şêr şeklinde telaffuz ediliyor. Bu kelime Azerbaycan Türkçesinde de şer olmuştur: Burda bir șer darda galıp bağırır (Haydar Baba).

3. Tac., Der. ve Osm. /k-/ > Fars. /g-/: Osm. kand (< Ar.) Tac. ve Der.'de känd, Fars.'da g̈änd; Osm. kutb (<Ar.) 'kutup' Tac. ve Der.'de kutb, Fars.'da ġotb vb. gibi. Osm. $k+a$, Tac. ve Der. $k+\ddot{a}$, Fars. $\dot{g}+\ddot{a}:$ Osm. kațre (<Ar.) > Tac. ve Der. käträ > Fars. gäträ/gätre gibi. Osm. $k+\bar{a}>$ Tac. ve Der. $k+\bar{a}>$ Fars. $\dot{g} \bar{a}$ : Osm. (<Ar.) kātil> Tac. ve Der.'de kātil > Fars.'da gātel; Osm. (< Ar.) kāäil > Tac. ve Der.'de kābil > Fars. gāäbel vb. gibi. Benzeri durumlar / $\dot{\mathrm{g}} /$ sesi için de geçerlidir. Ancak bu ses Farsçada değişmez. Yani Osm. $\dot{g}+a$, Tac., Der. ve Fars.'da $\dot{g}+a ̈$ oluyor: $\dot{g} a r i ̂ b ~>~ \dot{g} a ̈ r i ̂ b, ~ \dot{g} a m>\dot{g} a ̈ m$ gibi. Eğer /a/ sesi uzun ise Osm., Tac., Der. Farsça aynı oluyor, bu sıralamaya göre örnekleri şöyle gösterebiliriz: ġālib, gāllib, gāalib ve ġāleb. Son örnekte Farsçada /i/ sesi /e/ olmuştur.

4. Osmanlıcada ġayn $<\dot{\mathrm{g}}>$ ve kâf $<\mathrm{k}>\mathrm{h}$ harflerinde olduğu gibi, sâd $<s>>$, dat $<\mathrm{d}>$, tâ $<\mathrm{t}>, z \hat{a}<\mathrm{z}>, h \hat{a}<\mathrm{h}>$ ve $h \mathrm{~h}<\mathrm{h}>$ harfleriyle karşılanan harflerden sonra gelen ünlüler genellikle kalındır. Halbuki Tac., Der. ve Farsçada adı geçen seslerden sonra gelen ünlüler eğer vâv ya da elif ile karşıllanmıyorsa hep incedir: Sabr > säbr, zarar > zärär, taraf > täräf, zarf > zärf, hammâl > hämmâl, har 'eșek' > här gibi. Kalın 


\section{J(৫)}

/ḳ/ sesinden sonra gelen ünlünün Tac., Der. ve Fars.'da incelmesi kuralı Türkçe kelimeler için de geçerlidir: Türkçe kara Tac.ve Der.'de kärä, Farsçada g̈ärä. Eski yazıda yazılmış kelimeler için /a/, /u/, /i/ ünlülerinin karşıllı̆ı olan elif, vâv ve yâ harfleri varsa bu ünlüler uzun okunur: Türkçe kara süren Farsçada قره سوران yazıllyor ve g̈ärä sūrān okunuyor. Eski metinlerde I بايقرeklinde yazılan Bay Kara sözünü bugün Farsçada bazıları Bāyägrā şeklinde okurlar. قر اختاى Kara Hitay da Gärāhtāyy okunuyor.

Türkolojide Farsça sözlerin transkripsiyonu Osmanlıcada Farsça okunuşuna göre yapılır. Osmanlıcanın Farsçasında Farsçada hiç olmayan /ö/, /ü/ ve /1/ sesleri vardır. Kısacası, Farsçanın transkripsiyonu sözlerin Osmanlı telaffuzuna göre yapılır. Türkçede $\{+\mathrm{dAn}\}$ eki ile $\{+\mathrm{dA}\}$ eki Farsçada $e z$ ve der ayrı yazılır ve arkasından gelen kelimeyle bitiştirilmez, datif halinin Farsça karşıllı̆̆ be bazen بـ şeklinde ayrı yazılır به من gibi, bazen de arkasından gelen kelimeye bitişir بمن gibi. O yüzden ismin bu hâli be-men ya da bi-men şeklinde transkribe

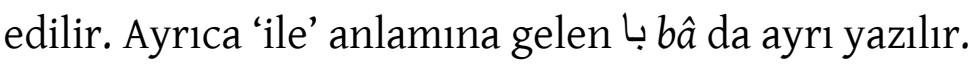

Son zamanlarda Türkiye'de yaygınlaşan Avrupalıların Farsça ve Arapça için kullandıkları transkripsiyon sisteminde Farsça açık /ä/ ve Arapçada fetha ile gösterilen açık /e/ ya da kısa /a/ ses hep /a/ ile gösteriliyor. Meselâ, Farsça 'Ben geldim' anlamina gelen män āmädäm söz konusu yeni transkripsiyon sisteminde man âmadam oluyor. Arapça äl-ḩamdu da al-hamdu şeklinde yazıllyor. Osmanlı/Türkçe transkripsiyonunda da bu söz el-ḥamdü oluyor.

KARE dergisinin 9. sayısında Turgut Koçoğlu ve Abdulkhalil Ahmadoughli tarafından yazılan Cüveynînin Târîh-i Cihân-güşâsı'ndaki Bazı Türkçe-Moğolca Kelimeleri Açıklayan Bir Lügatçe adlı makalesi çıkmıştır. Makalenin İngilizce özetinde Cüveynî tarihinin üç ciltte 1952-1960 yılları arasında yazıldığı belirtiliyor. Lügatçenin kendine özgü transkripsiyonu Osmanlıca Farsçasına göre yapılmıştır. Ancak yukarıda belirtilen ayrı yazılması gereken sözler arkalarından gelen sözlere bitiştirilmiş ve anlamsız sözler ortaya çıkmıştır. Meselâ bāliş tanımı yapilırken ... 'ibāret ezpan șad mišk̄āl est ... ibaresi Farsça değil. Farsçası şöyle olmalıydı: 'ibāret ez pānșda miškēal est. Farsçada ezpān yok.

Yazarın transkripsiyon sistemine benzetmeye çalışarak veriyorum:

Çün derin kitāb-1 müstetāb ki mevsūm est betārị̂n-i Cihān-güşā-yı 'Ațā Melik Cüveyni ba’ż1 elfāẓ-1 Türki⿱ -yi Çag̉atāyi d derțayy-1 'ibārāt-1 münderic ve dānisten-i berĥî ezḳavā'id-i ān hāāi ezmenfa'at nehvāhed būd. Betaḥrịr-i in muhtașar perdāhnt. (s.95). 
Bu aslında bir cümledir ve geleneksel Türkoloji transkripsiyonuyla yazllırsa şöyle yazmak gerekir:

Çün der în kitāb-1 müstețāb ki mevsūm bi-Tārîhn-i Cihān-güşā-yi cAtā Melik-i Cüveynî bacżî elfāz-ı Türkî-yi Çagagata'î der țayy-i cibārāt-1 münderic ve dānisten-i berĥî ez ḳavācid-i ān huālî ez menfacat nehvāhed būd, bi-taḥrîr-i în muhtașar perdāht.

Yukarıdaki yanlış okunan metnin anlamı da yanlış olur elbette. Ben metnin tamamını gözden geçirecek değilim. Yalnız kelimelerin açıklanmasında da yanlış okumalar var. Bemacnā ile başlyan cümleler doğru değil. Farsçada bi-macnî-yi ... est 'anlamina gelir' demek. Şehrîst 'şehrî est' demek. Etrek: Şehr isst yazılmaz. Bu Farsça değildir. Transkripsiyon yapılmasaydı sadece çevirisi yapılsaydı daha iyi olurdu belki. Tanımlanan kelimelerin okunmalarında hatalar var. Errān çü perrān demek 'perrān vezninde' demek. Bu da Arrān olmaz Errān olur. Ferheng-e Fârsînin A'lâm bölümğnde de böyle okunuyor. Ortaḳı da ortakî olmalıydı. Sondaki ünlü yâyı nisbettir, 'ortaklık' anlamına gelir, merd > merdî örneğinde olduğu gibi. Aygur da Uygur olmalıydı; buradaki tanımda da Bema'nā, bi-macnî-yi ve vaktā ki de vakttî ki olmalıydı. Bi-vezn-i ceberūt dendiği zaman Elemūt olur, Türkçede olduğu gibi Alamūt değil, zaten Farsçada Elemūt denir. Kelān vezninde deniyorsa söz konusu kelime Elān olur, Alan değil. Tabii, ben burada metnin tamamındaki hataları gösterecek değilim. Yazarları bilimsel çabaları için kutluyorum.

Aşağıda lügatçenin metninin transkripsiyonunu Osmanlı Farsçası olarak veriyorum:

Bismi'llāhi'r-raḥmāni'r-rahîm

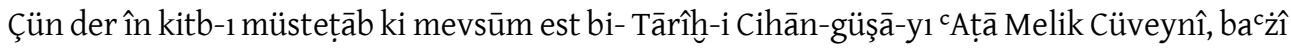
elfāz-1 Çağatā'î der țayy-1 cibārāt-1 münderic ve dānisten-i berḩî ez kavā'id-i ān hālî ez menfacat nehvāhed būd, [în bende-i hakîir] bi-tahrîr-i în muhtașar perdāhnt. Evvelen ehālîyi Maverā’ü'n-nehr ve țavāyif-i Özbek ki der Tūrān-zemîn iḳāmet dārend pāre'î kelimā rā bā kāf-i Arabî tekellüm minümāyend. Ammā ehl-i Hुvārezm ve Türkmānhā hemān lafẓ rā bā kāf-i Fārsî telaffuẓ mikünend. Țāniyen der nüvişten bacîî ḥurūf [rā] mînüvîsend ammā der huvānden bi-ān tenațtuk nemînümāyend, mānend-i nigāşten-i elif ve vāv ve yā' cihet-i tebyîn-i fetha ve żamme ve kesre, velî în ḳācide hem cumūmiyet nedāred. Dîger ānki gāhî dāl ve tā'-i ḳaraşet bi-yekdîger tebdîl mîşeved min gaayr-1 ițtırād ve hemçünîn tebdîl-i gaayn ve kậf ve hă̄' der heme cā mücevvez nîst. Mețelen yaġmak bi-macnî-ye bārîden hemîşe bā gaayn nüvişte mîşeved ve yaḳmaḳ bi-macnî-yi ḩarāb kerden ve ḳorḳu bi-manî-yi ḩavf [rā] dā’imen bā ḳāf nüvîsend, bi-hilāf-i ḳırǵı ve ḳıg̉avul ki tebdîl-i g̉ayn-ı vusțā-yı ānhā bi-ḳāf cāyiz ${ }^{5}$ est ve hākezāa mübādele-i sîn-i mühmele bi-șād-1 mühmele ve tā'-i ḳaraşet bi-țā'-i

5 Metinde hāyiz yazılmış. 


\section{Ј(@)}

huutṭ̂i ve dāl-i mühmele mānend-i su ki cibāret ez ābe est ber șu, ve toḳuz bi-macnî-ye nüh ber țoḳuz ve at bi-macnî-yi esb ber ad, ve gāhî hem bi-vaḳt-i irāde-i te'nît ber āḩir-i kelimāt mîm ilḥāk künend, mițl-i bég ve bégüm ve ḩan ve hanum. Hemçünîn gāhî hạrf-i kāâf-1 āḩiri kelimāt rā bi-ġayn-1 mucceme tebdîl nümūden cāyiz est, mānend-i laf̣̣-1 yak ki emr biharāb kerden est yag̉ güften ve nüvişten galaț nîst. İcmālen çün hod-ı māhā ehl-i lisān nîstîm ve kitābî hem muhtevî ber ḳavācid-i resm-ül-ḩațț-1 mușțalahāt-ı Türkî-yi Çag̉atay

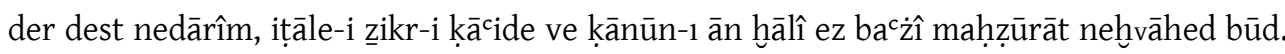
Enseb ānest ki be tavzîị ve tebyîn-i pāre'î luggāt ki der hîn-i müțālaca bi-în kitāb muhtāc hvāhed būd, iktifā kerde şeved.

“Atâ Melik-i Cüveynînnin Târîh-i Cihân-güşa'sı olarak bilinen bu değerli kitapta ibarelerin içinde Türkçe Çağatay sözleri yazılmış olduğundan ve onların kurallarının bilinmesinin yararsız olmayacağından bu kısa sözlüğün yazılmasına karar verildi. Evvelâ Mâverâü’nnehr ahâlîsi ve Turan yurdunda ikâmet eden Özbek tâ'ifeleri bazı sözleri kâf-i Arabî /k/ ile telaffuz ediyorlar. Sâniyen, yazarken bazı harfleri yazıyorlar, ama teleffuz etmiyorlar. Meselâ fetha, zamme ve esre için elif, vâv ve yâ harfleri yazıllyor (ama okunmuyor). Ama bu durumun yaygınlaşmış kuralı yoktur. Bazen de bir usûl ve tertibe tabi olmaksızın dâl ve tâ$i$ karaşet قرشت birbirinin yerine geçerler. Gayn, kāaf ve ha harflerinin biribirinin yerine

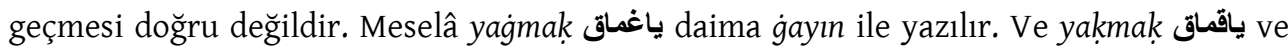

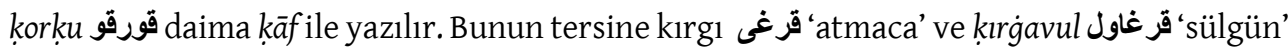
örneklerinde ortadaki gayın, kāaf olabiliyor. Aynı şekilde sîn harfi sâd olabiliyor, tâ-i karaşet de tâ-i hutțî̂y حطى ve dâl harfine dönüşebilir. Meselâ سو su şeklinde, tokuz توقوز da sقeklinde ve at ad yazılabilir. Bazen de dişilliği belirlemek için kelimenin sonuna bir mîm eklenir: Meselâ bég > begüm بيكم > بيك ve han > hanum خانم > خان olur. Bazen kelime sonundaki kậf, gaayın harfine dönüştürülebilir, meselâ 'yık' anlamına gelen yak بانق kelimesini ياغ yazmak ya da söylemek yanlış değildir. Kısacası, kendimiz dilci olmadığımız için ve elimizde Çağatay Türkçesinin yazım kılavuzu bulunmadığından dolayı kuralları açıklamak kolay olmayacaktır. En uygun olanı, sözlerin, bu kitap okunurken gerekli olanlarıyla yetinmektir."

\section{Bâb-ül-Elif}

Abaġa: Nām-ı püser-i Hülagū Han est. Hülagû Han'ın oğlunun adı.

āçār: Mîve ve hubūbāt rā gūyend ki bā turşî terbiye kerde bāşend. Turşu ile terbiye edilen meyve ve hububata denir.

Afşār: İsm-i țā'ife '̂̀'st ez etrāk. Türklerin bir boyunun adıdır. ${ }^{6}$

ag̊ruk: Bi-macnî̀-yi ị̣māl ve isḳāl est. Yük ve ağırlık anlamına gelir.

6 Eski Türkçede $A f s ̧ a r$ 'ın /f/ sesi üç noktalıdır ve Arapça vav harfi ve İngilizce /w/ gibi telaffuz edilir. Su kelimesi çok eski metinlerde sin ve üç noktalı <f> ile yazılır ve Türkmencede suw şeklinde telaffuz edilir. Türkmencede Af̧̧ar da Awşar ya da Owşar şeklinde söylenir. 
al tamgia: Mürekkeb ez dü lafž est, ahkāmm-ı selāțîn ve ümerā-yl Moğol rā gūyend ki bi-surhînüvişte bāşend. İki kelimeden oluşmuştur; kırmızı renkte yazılı olan Moğol sultan ve emîrlerinin hükümlerine denir.

al: Bā hemze-i memdūde ve lām-i sākin reng-i kırmız rā gūyend. Uzun elif ve harekesiz lām ile kırmızı renk demek.

Ala Kạak: Nām-ı mevżiĉ̀ est ki ez āncā şehr-i Kayalig heft rūze rāh'est. Bulunduğu yerle Kayalıg şehrinin arasında yedi günlük yol olan bir yerin adı.

alp: Bi-macnî-ye şücāc ve bahadır ve pehlivān est. Yiğit, bahadır ve pehlivan anlamina gelir.

Altay: Nām-ı mevżicî est der Türkistān ki vefāt-ı Kara Hülagü bin Maskan ibn-i Çaǵatay der ān mevżic būd. Türkistan'da Kara Hülagu bin Maskan ibn-i Çagatay'in vefat ettiği yerin adi.

altun: Țlā ve zer rā gūyend. Altın ve zer için kullanılır.

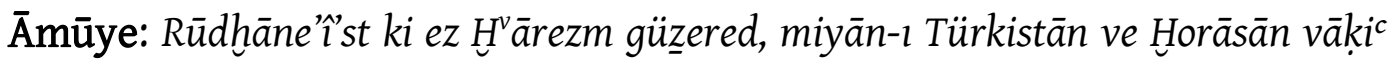
est. Harezm'den geçen ve Türkistan ile Horasan'ın arasında bulunan bir nehir.

Arı̀g Böke: Nām-ı yekî ez birāderān-ı Mengü Kaan est. Mengü Kaan'ın kardeşlerinden birinin adı.

Ata bég: Bi-macnî-yi lele ve mürebbî-yi pādişāh ve nāzır ve nāzım-ı umūr-ı devletî est. Padişahın [çocukken] bakıcısı ve eğiticisi ve devlet işlerine nezaret eden ve onları düzenleyen anlamına gelir.

Ayġaḳ/Ayḳak: Bi-macnî-ye ġammāz ve nemmām ve suhan-çîn est. Gammazlık eden dedikoducu, söz götürüp getiren anlamına gelir.

Eberkūh: Şehrekî est karî̉b bi-İșfahān, mucarrab-ı ān Eberkūh est. Isfahan'a yakın küçük bir şehir; Arapçası Eberkūu'tur.

Él Arslan: Nām-ı püser-i Atsız Hل⿳亠丷⿵冂rezm Şāh. Atsız Harezm Şah'ın oğlunun adı.

Elaḳçı: Nām-ı püser-i Sertak bin Batu Han. Sertak bin Batu Han'ın oğlunun adı.

Elān: Bi-feth-i evvel ber vezn-i kelān, nām-ı vilāyetî est ez Türkistān. Birinci harfi fethalı ve kelān vezninde, Türkistan'da bir vilâyetin adı.

Élçitay Noyan: Nām-ı birāder-i Çengîz Han est. Cengiz Han'ın biraderinin adı. 


\section{J()}

Elemūt: Ber vezn-i ceberūt nām-ı kal'cầ’st mābeyn-i Kazvîn ve Gîlān ki Hasan

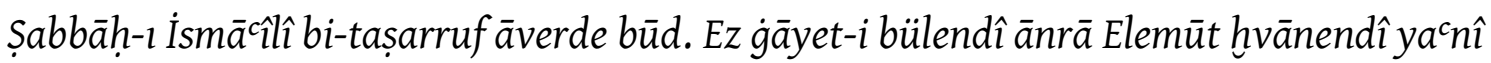
āşyāne-i ${ }^{c} u k a \bar{a} b$, çe ele bi-macnî-ye āssyān ve mūt cukāb est. Ceberût vezninde; Hasan Sabbah İsmâ̂llînin ele geçirdiği Kazvîn ile Gîlân (Geylân) arasında bulunan bir kalenin adı. Çok yüksek olduğu için ona ele mût demişler ve 'kartal yuvası' anlamina gelir, ele 'yuva', mût da 'kartal' demek.

elincik: Yacnî raciyyet-perver. Yani raiyyet-perver 'halkını seven'.

Elmalı̣ ve Almalığ: Nām-ı şehrî est der țaraf-ı şimāl-i Türkistān, mesken-i țâîfeyi Uyg்ur ez tavāyif-i Moğol. Moğolların bir boyu olan Uygurların yurdu Türkistan'ın kuzeyindeki bir şehrin adı.

Émil ve Émîl: Nām-ı mahall-i ikāmet ve ordu-yı kadîm-i Güyük Han ibn-i Oktay Kaan est. Güyük Han ibn-i Oktay Kaan'ın yaşadığı yerin ve eski konaklama yerinin adi.

Endhūd: Nām-ı şehrîsst der memālik-i Horāsān. Horasan bölgelerinin birinde bir şehir adı. ${ }^{7}$

Er Tak: Nām-ı kūhı̂’st der Karaḳorum. Karakorum'da bir dağın adıdır.

Erbil: Şehrîsst der ḳurb-ı Mūṣul. Mûsul'un yakınında bir şehirdir.

Ergen Gül: Nām-ı merǵzārî est der havālli-yi Semerkand. Semerkand civarında çayır çimenli ve çimekli bir yerin adı.

erk: Yacnî kal a-yı enderūn ve sarāy-ı hăkim-nişîn. İç kale ve içinde hükümdarın oturduğu saray.

erk: Ya $a^{c} n \hat{\imath}$ kalca-yi enderūn ve serā-yı hăkim-nişîn. İç kale ve hükümdarın oturduğu köşk demektir.

Erkenūn: Țāyfe'î'st ez millet-i Nișārā. Nisârâ halkından (hristiyanlardan) bir topluluk.

Ermen: Nām-ı vilāyetî est ez kūhistān-l Āzerbāycān ki mevlid-i Şîrîn āncā būd. Azerbaycan'ın dağlık bölgesinde Şî̂n'n'in doğduğu yer olan bir vilâyetin adı.

\footnotetext{
Afganistan'da Endhūuy var.
} 


\section{1)}

Errān: Çü perrān, vilāyetî est ez Azerbāycān ki Berdac ve Gence ve Beylakāan ez şehrhā-yl ān est. Perrân vezninde, Berda', Gence ve Beylaḳān şehirlerini içine alan bir Azerbaycan vilâyetidir.

Ertigin Noyan: Nām-ı birāder-i Çengiz Han est. Cengiz Hanı'ın erkek kardeşinin adı.

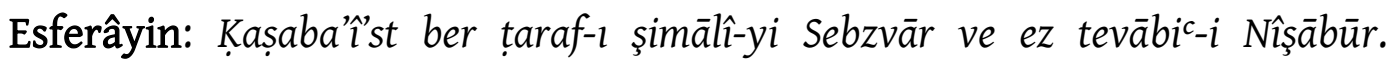
Sebzvâr'ın kuzeyinde bulunan ve Nişâbûr'a bağlı olan bir kasabadır.

Etrek: Şehrîst vāḳic der şimāl-i Îrān ki mesken-i țā'ife-i Türkmān est. İran'in kuzeyinde Türkmenlerin yaşadığı bir şehir.

İdi Kut: Bi-żamm-i kāâf, mürekkeb ez dü lafz est bi-macnî-ye șāhib-i baht ve ikbāl ve

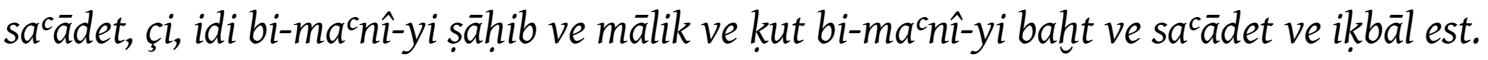
Kaf harfinin zammiyle, iki kelimeden oluşmuştur ve 'baht, saadet ve ikbal sahibi' anlamına gelir, çünkü idi ‘sahip ve mâlik, iye’ anlamına gelir, kut da 'baht, saadet, ikbal' demektir.

işik/éşik: Bi-macnî-yi bārgāh ve āstāne ve işik akass yacnî re'îs-i bārgāh. Dergâh ve âstâne anlamına gelir ve işik ag̉ası ${ }^{8}$ yani 'bir dergâhın ya da büyük bir merkezin reisi'demek.

Og̉uz: Yacnî pāk-fițrat ve nām-l yekî ez ecdād-ı selātîn-i Türk est ki Ümerā ve havānîn-i Türk bi- $\bar{u}$ mensūbend. İyi karakterli demek ve Türk hükümdarlarının ecdadından birinin adı, Türk emîrleri ve hanları ona mensupturlar.

Oḳta: Bi-macnî-yi bahadır ve pehlivān, pür-zürve kuvvet est ve ism-i püser-i Çengiz

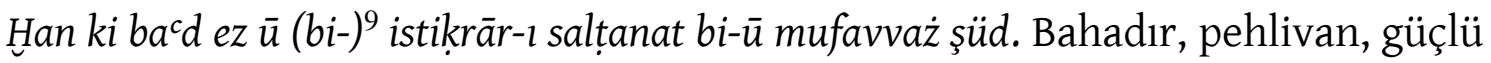
kuvvetli anlamına gelir ve Cengiz Han'in ölümünden sonra onun yerine geçen oğlunun adıdır. ${ }^{10}$

olcay: Yacnî meymenet, sacādet ve iḳbāl. Meymenet, saadet ve ikbâl anlamina gelir.

Olcaytu: Șāhib-i meymenet ve iḳāl ve nām-ı püser-i Arg̈un bin Abaḳa bin Hülagu. Meymenetli, bahtlı demek ve Argun bin Abaka bin Hülagu'nun oğlunun adı.

\footnotetext{
8 Metinde aḳası yazılmış

9 Bu ön ek fazla.

10 Bu ad daha sonra Oktay yazılmıştır.
} 
ordu: Mahall-i nüzūl-i leşker-i sulțānî. Padişahın ordusunun konakladığı yer.

Orḩan: Nām-ı yekî ez püserān-ı Çengiz Han. Cengiz Han'ın oğullarından birinin adi.

orḳun: Nām-ı mevziicî est ki der ān şehr-i Ordu Balig binā nihāde şüde est. Ordu Balığ’ın bina edildiği yerin adı.

ortak: Bi-macnî-yi enbāz ve şerîk der ticāret ve bāzergānî. Ticaret ortağı anlamina gelir.

ortakîi: Yacnî şirket kerden der ticāret. Ticarette ortaklık demek.

oturak: Mahall-i ikāmet ve menzil-i nişîmen. İkamet edilen ve içinde oturulan yer.

Otuz İki: Nāml- kabîle’̂̀st ez Etrāk. Türklerin bir kabilesinin adı.

Oylaç: Nām-l țāyfe'î̀st ez Etrāk. Türklerden bir taifenin adı.

oymak: Kabîle’̂̀st ez Etrāk. Türklerin bir kabilesi.

Oyrat: Kabîle’̂’st ez Etrāk. Türklerin bir kabilesidir.

Öngüt: Nām-l kabîle’̂’stst ez țavāyif-i Etrāk. Türk taifelerinden bir kabilenin adı.

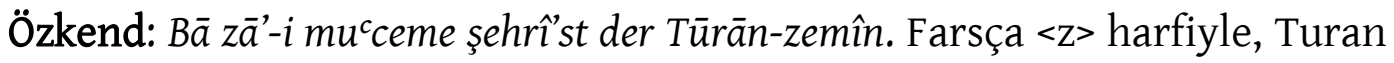
yurdunda bir şehridir.

ulag̉ ve ulaḳ: Bi-macnî-yi bārgîr ve tahmîl est. Beygir ve yük hayvanı anlamına gelir.

Ulug Noyın: Lakab-ı Toli Han bin Çengiz Han, yachî sipeh-sālār-ı a $a^{c}$ zam. Cengiz Han'ın oğlu Toli'nın lakabı, yani büyük komutan.

Ulug Ṭaḳ: Mevizici est miyān-ı Karaḳorum ve Biş Bahı̉. Karakorm ve Biş Balıg arasinda bir yerdir.

uluğ: Bi-żamm-i evvel ve țānî ve sükūn-i ġayn-ı mucceme bi-macnî-yi büzürg ve ecell ve $a^{c}$ zam est. Birinci ve ikinci harfin zammeli ve gayn harfinin harekesiz olmasıla, büyük, yüce ve azametli anlamına gelir.

ulus: Bi-macnî-yi habîle ve asşîret ve țāyfe est. Kabile, aşiret ve taife anlamına gelir. 


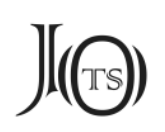

uruğ: $B i-m a^{c} n \hat{n}-y i$ nesl ve sülāle ve evlād ve $a^{c}$ kāb est. Nesil ve sülale, ahfâd ve eslâf anlamina gelir.

Uş/Oş: Nām-ı şehrîsst der Türkistān. Türkistan'da bir şehrin adı.

Utrār: Bi- żamm-i evvel ve sükūn-i tānî șehrîst der Māverā'ü'n-nehr ki ser-hadd-i vilāyet-i Türkistān est. Maveraünnehr'de Türkistan'in serhaddi olan bir şehrin ad. $^{11}$

Uygur: Bi-macnî-yi çesbende est ve nām-i țāyfe'î'st ez Etrāk. Der vaktî ki Og்u Han rā bā akvām-ı hod münāzacat üftād, baczî̀ ez ānhā cānib-i Ogjuz Han ra giriftend ve mülaḳcab ber Uyg்ur şüdend, yacnî bi-mā peyvest ve mu'āvenet kerd. 'Yapışkan' anlamına gelir ve Türklerden bir taifenin adıdır. Oġuz Han kendi kavimleriyle kavgaya giriştiği zaman onlardan bazıları Oguz han tarafını tuttular ve 'bize katıldı, uydu ve yardım etti' anlamında onlara Uyğur dediler.

Uyg்ur: Nām-ı kabîle’̂̀st ez kabāyil-i Etrāk. Türk kabîlelerinden bir kabîlenin adi.

ülke: Bi-macnî-yi diyār ve memleket est. Diyar ve memleket anlamina gelir.

Ürgenc ve Ürgānc: Dü şehrîst der nāhiyet-i Hvārezm, yekî Ürgenc-i Nev, dîgerî Köhne. Harezm'de iki şehir var; biri Yeni Ürgenc, diğeri Köhne Ürgenc. ${ }^{12}$

\section{Bâb-ül-Bâ}

Bādğîs: Bi-sükūn-i dāl-i mühmele ve kesr-i ġayn-ı mucceme nāhiyetî est müştemil bir kurā'-ı bisyār ve acmāl-i Herāt ve lafz-ı Bādg̀îs muªrrab-ı bād-hî̀z est, çün der ān nāhiyet bād besyār mîvezîd, bi-în ism mevsūm gerdîd. Dal harfinin harekesiz olması ve gayın'ın esre ile okunmasıyla, Herat'ın nahiyelerinin birçok kasabalarını içine alır. Farsça Bâdĝ̣is ‘çok rüzgârlı' anlamına gelen bâd-hîz'ın Arapçada kullanılan şeklidir. Zira bu bölge çok rüzgârlı olduğu için böyle adlandırılmıştır.

Bäglān: Şehrîst der Türkistān, bi-nezdîkî-yi Belh. Türkistan'da Belh'in yakınında bir şehir.

\footnotetext{
11 Farsçada otrār.

12 Bu şehir hakkında makalenin girişinde açıklama var.
} 


\section{ग(৫)}

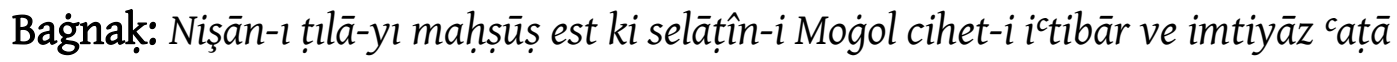
mîkerdend. Moğol hükümdarlarının bir ayrıcalık, bir üstünlük için verdikleri özel alltın madalya.

bahadır: Yacnî merd-i şücāa ve dilîr. Yani, yürekli, cesur adam.

Baharçin: Nām-ı püser-i Kaydu Han est. Kaydu Han'ın oğlunun adı.

bahatur: Bi-macnî-yi bahadır ve şücăc ve dilîr est. Bahadır, yiğit ve cesur anlamina gelir.

Balasaḳun/Balasaġun: Şehrî̀st der Türkistān ki ānrā Ġur Bahig ${ }^{13}$ gūyend. Türkistan'da Gur Balig ${ }^{14}$ olarak da bilinen bir şehir.

balıg ve balık: bi-machî-yi şehr ve vilāyet est. Şehir ve vilâyet anlamına gelir.

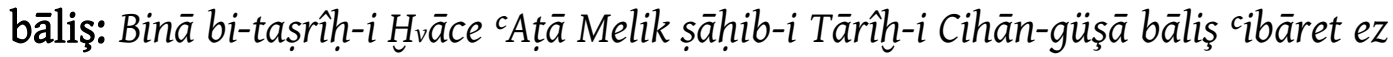
pānșad mițkāl est, hhvāh zer bāş̧d yā nukra. Ammā der bacìî lugāatt-ı Türkî mînüvîsend bāliş-i zer cibāret ez dü hezār dînār est ve bāliş-i nukra ez düvîst dînār. Elbette der îngūne

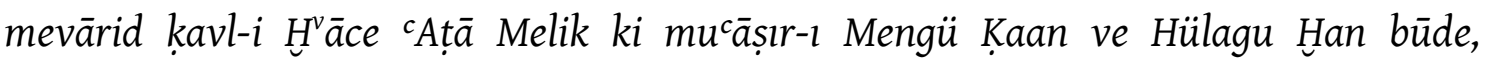

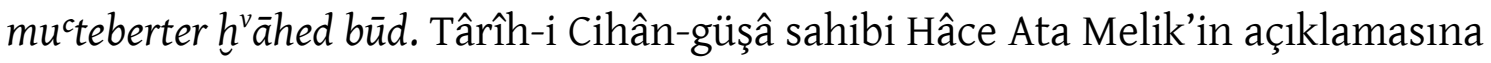
göre bāliş, beş yüz miskâl altın ya da gümüştür. Ama bazı Türkçe sözlükler altın bāliş'in iki bin dînâr, gümüş bāliş'in de iki yüz dînâr değerinde olduğunu yazıyorlar. Elbette böyle durumlarda Mengü Kaan ve Hülagü Han'ın çağdaşı olan Ata Melik'in sözü daha muteber olacaktır.

Bâmiyân: Şehrî est miyān-i Kābul ve belh. Kâbil ve Belh arasında bir şehir.

Barakç̧in: Nām-ı zevce-i Batu bin Tuşi Han est. Tuşi Han'ın oğlu olan Batu'nun zevcesinin adl.

Beranḡār: cibāret ez meymene-i ve dest-i rāst-ı leşker ve ordu est. Ordunun să̆ tarafına denir.

basḳak: Bi-macnî-yi żābıt ve hăfiz ve muhteseb est. Zâbıt, koruyucu ve belediye ve polis görevlisi anlamina gelir.

Başğırd: Açıklama yok.

13 Birçok yazmada bu söz Ǵuz Bahı̀ şeklinde geçiyor.

14 Metinde Guz Bahig. 


\section{J(৫)}

Batu: Bi-macnî-yi kavî ve ziber-dest ve nām-ı püser-i Tuşi Hुan bin Çengiz Han est ki bi-mezîd-i şevket ve übbehet ber sāyir-i evlād- l Çengiz imtiyāz dāşst. Zîrā ki vefāt-ı Tuşi Han şeş māh kabl ez fevt-i Çengiz Han ittifäk üftād ve Çengiz Han Batu rā bi-cā-yı pedereş hükm-rān-ı Hुoārezm ve Deșt-i Hazar ve Bulġar ve Elān ve ān hudūd fermūd. Bacd ez Çengiz Han Okta Kaan nîz camel-i ū rā imżā ve Batu rā ber cemî́ci evlād-ı Çengiz Han mukaddem mîdāş̧t. Vefät-l Batu der sene-i erbaca ve hamsîn ve sitte mi'e būd. Güçlü ve becerikli anlamına gelir ve Cengiz Han'ın oğlu Tuşi Han'ın oğlunun adıdır. Batu haşmeti ve heybetiyle Cengiz Han'ın diğer evlatlarına göre imtiyazlıydı. Zira Tuşi Han'ın ölümü Cengiz Han'ın ölümünden altı ay önce oldu ve Cengiz Han Batu'yu babasının yerine Harezm, Deşt-i Hazer, Bulgar, Elan gibi bölgelerin hükümdarı tayin etti. Cengiz Han'dan sonra Oktay Kaan da onun görevlerini onayliyordu ve Batu'yu Cengiz Han'ın bütün evlatlarından üstün tutuyordu. Batu 654'te vefat etti.

bâverçi: Asş-pez ve țabbāhh rā gūyend. Aşçı ve yemek pişirene derler.

Bāverd: Bi-feth-i vāv ve sikūn-i rā' ve dāl-i bî-nokța, nām-ı belde '̂̀'st der Hुorāsān. Fethalı vâv ve râ harfi ve noktasız dal harfinin harekesizliğiyle, Horasan'da bir beldenin adi.

Benāket: Şehrîst der Maverā'ü’n-nehr, muªrrab-ı Fenāket. Maveraünnehr'de bir şehir; Fenāket'in Arapça şeklidir.

Berdān: Nām-ı mevżicî est vāḳı ${ }^{c} a$ der miyān-ı Ġazneyn ve Bāmiyān. Ġazneyn ve Bāmiyān'ın arasında bulunan bir yerin adı.

Berke Oġul: Nām-ı yekî ez püserān-ı Cuci Han est. Cuci Han'ın oğullarından birinin adı.

Berkcār: Nām-ı yekî ez püserān-ı Cuci Han est. Cuci Han'ın oğullarından birinin adi.

Bervān: Bi-vezn-i merdān, nām-l şehrî̀st karîb bi-Ġazneyn. Merdān vezninde, Ġazneyn'e yakın bir şehrin adı.

Beyhak: Nāhiyetî est ez tevābici Sebzvār. Sebzvâr'a bağlı bir nahiye.

Bégi: Der în kitāb cibāret ez Serḳutni Bégi, māder-i Mengü Kaan est. Bu kitapta Mengü Kaan'in annesi Serḳutni Bégi söz konusudur. 


\section{1)}

Biliktay Noyan: Nām-ı yekî ez birāderān-ı Çengiz Han est. Cengiz Han'ın kardeşlerinden birinin adı.

Biş Balığ: Mevżicîest der Türkistān der nezdîk-i memleket-i Çîn. Türkistan'da Çin memleketine yakın olan bir yerin adı.

Boġa Han: Nām-ı cedd-i heştüm-i Çengiz Huan est. Cengiz Han'ın sekizinci ceddinin adi.

Böçek: Nām-ı yekî ez birāderān-ı Mengü Kaan est. Mengü Kaan'ın kardeşlerinden birinin adı.

Buḳa Timur: Nām-ı birader-i Batu, püser-i Cuci Han bin Çengiz Han est. Cuci Han bin Cengiz Han'ın oğlu Batu'nun kardeşinin adı.

Bulġar: Şehrîst nezdîk bi-Z̧ulemāt, der zamān-ı İskender binā şüde. İskender zamanında bina edilen Zulemāt'a yakın bir şehir. ${ }^{15}$

Bulġay: Nām-ı püser-i Sentan bin Cuci Han bin Çengiz Han est. Sentan bin Cuci Han bin Cengiz Han'ın oğlunun adı.

Būrpeleng: Nām-ı mevżiĉ est miyān-ı Karaḳorum ve Biş Balig. Karakorum ile Biş Balıg arasında bir yerin adı. ${ }^{16}$

pāyize: Yacnî menşūr ve aḥkām-ı dîvānî. Ferman, tezkere ve dîvan hükümleri demek.

Pencāb: Vilāyetî est ez Sind ki penc rūd ez ețrāf-ı ān mîgüzered. Sind'in, çevresinde beş nehir akan bir vilâyetidir.

petik: Bi-macnî-yi mektūb est ve petikçi kātib ve nüvîsende rā gūyend. Yazılmış yazı anlamına gelir ve petikçi 'kâtip ve yazar' demektir. ${ }^{17}$

15 Bazılarına göre 'karanlıklar' anlamına gelen Zulemāt yılın yarısı karanlık olan, ikinci yarısında da ışığı az olan kuzey kutbuna yakın yerlerdir. Bir hikâyeye göre İskender ve Hızır âb-ı hayât'ı bulmaya gitmişler ve Hızır bu hayat suyunu içince ebediyen diri kalmış (Moin, 1381/V: 1116).

16 Farsçada būr 'açık renkli, kumral', peleng de 'kaplan' demek; yūz 'tazı', yūzpeleng de 'leopar' demek. Birinci kelime boz da olabilir.

17 Eski Türkçede bu söz betik'tir. 


\section{ग(৫)}

\section{Bâbü’t-Tâ}

Tabcu Noyan: Nām-l yekî ez ümerāa-yi Mengü Kaan est ki bā leşker-i girān bimuhāafazat-ı memālik-i Îran firistād ve bacd ez ū Hülagu Han rā me'mūr fermūd. Mengü Kaan'ın emîrlerinden biri; Kaan onu İran bölgesindeki memleketleri korumaya gönderdi. Ondan sonra da bu görevi Hülagu Han'a verdi.

Tācîk: Kavmîrā gūyend ki Fārsî-zebānend ve kabūl-i hü̈kūmet-i Etrāk rā kerde'end. Der Āsyā-yı Vusțā Fārsî-zebān rā Tācîk ve Türkî-zebān rā Türk mînāmend. Fars dilli olup Türklerin hükümdarlığını kabul eden bir kavim. Orta Asya'da Fars dillilere Tacik, Türk dillilere de Türk denir.

tag̉ar: Bā tā-i karaşet ve țāa-i hutțtî zarf-ı bü̈̈zrg-i sifālîn rā gūyend ve yek tag்ar ārd cibāret ez yek-șad men ārd est. Tâ-i karaşet ya da tâ-i hutțtîile yazllabilen bu söz büyük toprak kap anlamına gelir. Bir tagar dolusu un yüz batman olur.

Taġaşi: Nām-l zevce-i Yisu Mengü bin Çaġatay bin Çengiz Han est. Yisu Mengü bin Çagatay, bin Cengiz Han'ın zevcesinin adı.

Taḳaḩar Köreken: Cengiz Hanîn damadının adı. ${ }^{18}$

tamġa: Bi-macnî-ye ețer ve nişāne ve mühr ve mektūb'est. Eger bā ḳırmiz ve surhî̀ nüvişte bāşend ānrā al tamg்a gūyend ve eger bā siyāhî ve mürekkeb nüvîsend kara tamg்a ve eger bāa āb-ı țllā nüvişte bāşend altun tamg்a gẓyend. İz, belirti, mühür ve yazı demek; eğer kırmızı renkte yazılmışsa ona al tamǵa denir, eğer siyah renkte ve mürekkeple yazılmısssa ona ḳara tamǵa derler, eğer altın suyu ile yazılmışsa da ona altun tamg்a derler.

Tancut: Nām-ı kabîle’̂̀sst ez Etrāk münteseb bi-Carka Lengüm, püser-i Kaydu Han.

Tārāt: Karye'î'st der se fersahî̀-yi Buhārā. Buhara'dan üç fersah uzaklıkta olan bir kasaba.

tarhhan: Ez cümle-i elkābî est ki selāțîn-i Türkistān ve Māverāäün-nehr în imtiyāz ra bi-kemter kesî icțā mîfermūdend. Ve Macnî-y ān mu'āa ve müsellem ez tekālîf-i dîvānî est. Ve hemgām-i istîlā ve istiklāl-i Çengiz Han, șāhibān-ı în lakab dārāa-yı imtiyāzāt-l tisca būde'end. Evvelā tā nüh defca der șudūr-i hațāyā ve cerāyim-i 'cazîme mu'āteb ve mu'āhaz nemîşüdend. Tāniyen, tā nüh puşt evlād ve ahfād-l anhā rā ez taḥmîlāt-ı dîvānî mucāf mîdāştend. Tālisen, der ġazevāt ve hurūb ez ġanāyim-i me'hūze-yi ānhā 'öşr-i dîvānî

18 köreken, Türkmencede 'damat' demek. 
muțālebe nemînümūdend. Rābican, bidūn-i istîz̄ān bi-bārgāh ve ḥużūr-l sulțān vārid

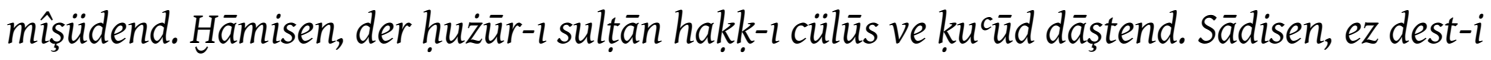
hod-ı sultān istihkkāke-ı ahzz-ı nüh cām-ı şerāb ve bi-în mevhibet imtiyāz dāştend. Sābican, der ețnā-yı seyr ü sefer pîşā-pîş-i sulțān mîreftend. Țāminen, sivā-yı duhterān-ı sulțān, duhter-i herkes rā mîh hāastend, bidūn-ı ižn ve icāze-'i evliyā-yı ù bi-harem-sarā-yı hod mîburdend. Tāsican, cevāyiz ve cațāyā-yl ānhā ez cānib-i sulțān ez kabîl-i esb ve libās ve hayme ve hargāh ve sāyir-i esbāb-l tecemmül ez nüh caded kemter cāyiz nebūd. Türkistan ve Maveraünnehr sultanlarının çok az sayıda kişilere verdikleri ayrıcalık; bunun yararı divan prosedüründen muaf olmaktır. Cengiz Han'ın istilâ ve istiklâl törenleri sırasında böyle lakabı olanların dokuz imtiyazları vardı: 1. Hata ve cerimelerle ilgili suçlarda dokuz kereye kadar cezalandırılmazlar. 2. Dokuz nesil sonrasına kadar evlâdı ve ahfâdı Divan yükümlülüklerinden muaf tutuluyordu. 3. Çatışmalarda ve savaşlarda ellerine geçirdikleri ganimetlerden Divan öşürü talep edilmiyordu. 4. Köşke ve padişahın huzuruna izinsiz girebiliyorlardı. 5. Sultanın huzurunda oturup kalkabiliyorlardı. 6. Sultanın kendi elinden dokuz şarap bardağını alma istihkakıyla bir ayrıcalık sahibiydiler. 7. Seyr ü sefer sırasında sultanın önünde yürüyorlardı. 8. Sultanın kızları hariç istedikleri kızı anne babasının izni olmadan haremlerine götürebiliyorlardı. 9. Sultanın verdiği at, giysi, çadır ve başka süs eşyaları gibi ödüller ve bağışların sayısı dokuzdan az olması caiz değildi.

Taşkend: Şehr-i mucteberî est der Türkistān. Türkistan'da muteber bir şehir.

Tat: Kavmî rā gūyend ki Türkî-zebānend ve kabūl-i hükūmet-i Etrāk rā kerde end. Türk dilli olup Türklerin hükümdarlı̆̆ını kabul eden halka derler. ${ }^{19}$

Taynḳu: Nām-ı emîrî est ez ümerā-yı Gür Han, sulțān-ı memleket-i Hıtta ki ù bā leşker-i girān ez cānib-i Gür Han bi-ceng-i Sulțān Muhammed Hل̄ârezmşāh me'mūr ve der ceng dest-gîr ve der Hुvarezm maḳtūl şüd. Hitâ ülkesinin sultanı Gür Han'ın emîrlerinden bir emîrin adı. Gür Han onu büyük bir ordu ile Sultan Muhammed Harezmşah'la savaşmaya gönderdi. Savaşta esir oldu ve Harezm'de öldürüldü.

19 Tatlar bugün kafksya'da ve özellikle Azerbaycan'da yaşayan İranî halktır. Dilleri Tatî, İranî dillerdendir. Türk kavimleri tarih boyunca kendilerinden olmayan yerlilere Tat demişler. Bugün Özbekler Taciklere, Türkmenler de Farslara Tat derler. Şöyle bir atasözü var: Tat'in doğrusu, orağın eğrisi! 


\section{ग(৫)}

Tāzîk: Evlād-ı ${ }^{c}$ Arab rā gūyend ki der ${ }^{c} A c e m$ zā'îde ve büzürg şüde bāşed. Acem diyarında doğup büyüyen Arap evlâdına derler. ${ }^{20}$

tegişmiş: Yacnî hedāyā ve pîş-keş ki bi-ḥużūr-ı selāțîn takdîm mîşeved. Sultanlara takdim edilen hediye ve peşkeşler.

tekemiş: Bi-macnî-yi sürcat vr şitāb est. Sürat ve acele anlamina gelir.

Teküt: Nām-ı yekî ez birāderān-ı Çengiz Huan. Cengiz Han'ın kardeşlerinden birinin adi.

Temmîşe: Bi-feth-i tā ve kesr-i mîm-i meşdūd ve yā-yı mechūl, bîşe'̂̀sst der nevāhî̀ye Āmul-i Māzenderān. Ta harfini fetha ile mîm harfini de şeddeli okumakla Mazenderan bölgesinde, Âmul şehrine yakın bir yerde küçük bir ormanın adı.

Tenküt: Nām-ı yekî ez püserān-ı Cuci Han bin Çengiz Han ve ism-i nāhiyetî est der memleket-i Hitay. Cuci Han bin Cengiz Han'ın oğullarından birinin adı, ayrıca Hatay memlektinde bir nahiyenin adı.

Teyri/Tayrı: Yacnî yezdān ve perverdigār-ı cālemîyān. Dünya ahalisinin Allah'ı demek.

Terāz/Tarāz: Nām-ı vilāyetî est bi-țaraf-ı şimāl-i Ferġana ki ānrā Almalı̀ ve Yengi nîz gūyend. Fergana'nın kuzeyinde bir vilâyetin adı, ona Almalıg ve Yengi de derler.

Termed: Şehrî est meşhūr der Māverā'ün-nehr. Maveraünnehr'de ünlü bir şehir. ${ }^{21}$

tersā: Frrka-i Nașrānî rā gūyend, yacnî Îsevî-mežheb. Ve gāhî ez āteş-perest nîz tersā tacbîr mîşeved. Nasrânî fırkasından, yani Hristiyan dininden olanlara derler; bazen ateşe tapanlara da tersâ deniyor. ${ }^{22}$

20 Farsçada Tâzîk 'Türk olmayan, İranî' demek; Tâzî ise 'koşmak, saldırmak' anlamına gelen tāhten mastarından türemiştir. Tāzî, Türkçede tazı olmuştur. Araplara da belki saldırma özelliklerinden dolayı tāzî denir. Orta Farsçada yâ-yı nisbetin sonunda bir /k/ sesi vardır. Bu söz belki de Tācîk'e benzetilerek türetilmiştir. Köktürk yazıtlarında geçen Tezik, Arap harfleriyle yazıldığında Tāzik olmuş olabilir.

${ }^{21}$ Bu şehir bugün Termez adıyla Özbekistan'da.

22 Hristiyanlar için kullanılan tersā aslında Farsçada 'korkan, korkusu olan' demek. Rivayete göre Mevlânâ Hristiyanlar için 'Bunlar hiç olmazsa tersâ’ demiş, cenazesinde de daha çok Hristiyan varmış. 
tette: Bā evvel meftūḥ ve țānî müsşedded, nām-ı şehrî̀st ez bilād-i Send. Birinci $\langle t>$ fethalı, ikincisi fethalı ve şeddeli, Sind beldelerinden bir şehrin adı.

Toli: Bi-machî-yi āyine ve mir'āt ve nām-l yekî ez püserān-ı Çengiz Han est ki pederi Mengü Kaan bāşsed. Ayna anlamına gelir ve Cengiz Han'ın oğullarından birinin adı. $O$ da Mengü Kaan'ın babasıdır.

tovaçı: $B i-m a^{c} n \hat{n}-y i$ münādî ve carçı est. Seslenerek haber veren tellal anlamına gelir. ${ }^{23}$

toy: $B i-m a^{c} n \hat{i}-y i$ sūr ve sürūr ve velîme ve mihmānî-yi cumūmî est. Düğün ve eğlence, ziyafet ve umuma açık davet anlamına gelir.

toyin: cỉbāret ez kıssîsān-ı büt-perst est ki ruhbān ve keşîs güfte mîşeved. Bunlar putperest papazlardır ki onlara rahip ve keşiş de derler.

Többet: Bi-żammü't-tā ve feth-ül-bä'-ül-müşeddede, memleketî est miyān-l Çin ve Tataristān ve Türkistān ve Hindūstān ki der țaraf-ı şarkî̀-yi Keşmîr vākicic est. Ötreli <t> ve fethalı bir şeddeli <b> ile, Kâş̧îr'in doğusuna yerleşen ve Çin, Tataristan, Türkistan ve Hindistan arasında bulunan bir memleket.

Tun: Nām-ı kașaba'î’st der memleket-i Horāsān. Horasan'da bir kasabanın adı.

Turakina H'atun: Nām-ı zevce-i Okta Kaan, māder-i Güyğük Han. Güyük Han'ın annesi ve Okta Kaan'ın zecesinin adı.

Tūrān: Tūr nām-ı püser-i büzürgter-i Ferîdūn est. Der taksîm-i memālik bi-evlād-ı hod memleketî ra ki bi-ū dād bi-ism-i ū mevsūm ve Tūrān güfte şüd, yachî māl-i Tūr ve Tūrān gaayr-ı Türkistān būde ve hudūd-ı ān der eyyām-ı kadîm ez țaraf-ı cenūb

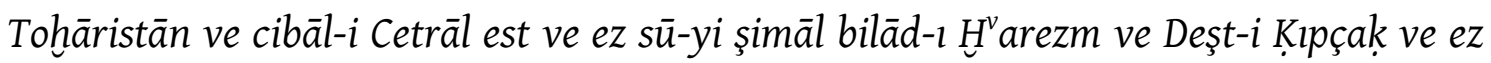
țaraf-ı mag̉rib diyār-ı Horāsān ve Cürcān ve ez sū-yi maşrılk arż-ı Türkistān ve Mog̉olistān ve cün $a^{c} r a \bar{b}$ ber ān vilāyet müstevlî şüdend bi-māverā'ü'n-nehr mevsūm şüd. Tûr, Ferîdûn'un büyük oğlunun adıdır. Ferîdūn, ülkelerini dağıtırken, büyük oğlu Tūr'a verdiği ülkenin adını onun adından alarak ona Tūrān demiştir. Bu, 'Tūr'a aittir' demektir. Tūrān, Türkistan'dan başkaymış ve eski zamanda güneyden Toharistan ve Cetral dağları, kuzeyden Harezm beldeleri ve Deşt-i Kıpçak ile, batıdan Horasan ve Cürcan diyarı ve doğudan Türkistan toprağı ve Moğolistan ile sınırlıdı, Araplar o bölgeyi istilâ edince de adı Maveraünnehr oldu.

\footnotetext{
23 Bu sözün ‘ordu müfettişi’ anlamı da var.
} 


\section{J(อ)}

turgùu: Bemachî-yi cative ve țacām est ki berāy-ı mihmān hāàzr ve müheyyā mîdārend ve bi-cArabîānrā nüzl gūyend bi-żamm-i nūn ve sikūn-i zāa'-i mucceme. Bağış ya da sadaka olarak misafir için hazırlanan yemek, Arapçada buna nuzl denir. ${ }^{24}$

Tuşi: Nām-ı püser-i evvel-i Çengşz Han est ki bacizî müverrihîn ez $\bar{u}$ Cuci tacbîr künend. Cengiz Han'ın birinci oğlunun adıdır. Bazı tarihçiler ona Cuci derler.

tutmaç: Aş̧̂ি est ki bā sumāḳ pezend. Sumakla pişirilen bir yemek.

Türk: Bi-żammü't-tā', ism-i püser-i evvel-i Yāfet bin Nūḥ 'aleyhi's-selām est ve nām-l han-l evvel-i havānîn-i Türkistan hem Türk būde est. Yâfis bin Nuh aleyisselâmın birinci oğlu, Türkistan'ın hanlarının birincisinin adı da Türk idi.

Türkan H'vatun: Nām-ı māder-i Sulțān Muhammed Hुārezmşāh est. Sultan Muhammed Harezmşah'ın annesinin adı.

Türkistan: Memleketî est vāḳı ${ }^{c}$ a der țaraf-ı şimālî-yi Taşkend der semt-i memālik$i$ Rusiye. Taşkent'in kuzeyinde Rusya bölgeleri yönünde bulunan bir memleket.

\section{Bâb-ül-Cîm}

Cācerm: Bi-fethli cîm-i țānî ve sükūn-i rā'-i mühmele vilāyetî est de Horasān. İkinci <c>'nin fetha ile ve ra harfinin sükûn ile okumakla, Horasan'da bir vilâyetin adi.

carçı: Yacnî muhbir ve muclin ve eşhāṣ̣̂ ki haber-i cülūs-i ve rükūb-i selāṭ̂n rā bimerdüm mîresānend. Yani haber verici ve ilân edici ve sultanların tahta geçişini haber veren kişi, tellal.

Carka Lengüm: İsm-i püser-i Kaydu H̦an est. Kaydu Han'ın oğlunun adı.

cebbe: Bi-macnî-yi cevşen ve eslihha-i harbiyye est. Cebbe-hāne yacnî enbār-ı esliḥa ve mahzen-i edevāt- 1 harb. Zırh ve silâh anlamına gelir, cebe-hâne de silâh ve savaş için gerekli malzemenin anbarı demek.

Celāyir: Nām-l kabîle’̂̀’st ez kabāyil-i Türk. Türk kabilelerinden bir kabilenin adi.

Cend: Bi-feth-i cîm ve sükūn-i nûn ve dāl-i mühmele şehrîest der māverāü̈n-nehr. Cîm'in fetha ile, nûn'un da harekesiz okunmasıyla, Maveraünnehr'de bir şehir.

24 Doerfer, bu sözü tuzǵu olarak da açıklanıyor (1963: 900). 
cerge: Așleş çirge est, kem kem bi-takfîf ve tahrîf cerge güfte mîşeved. Aslı çirge'dir, uzun sürede değişerek cerge olmuştur.

cerîde: Yacnî muhaffef ve sebük-bār. Yükü hafifletilmiş demek.

cevanġar: cíbāret ez meysere ve dest-i çep-i leşker ve ordu est. Ordunun sol tarafi demek.

Ceyhūn: Nām-ı nehr-i mucazzam ve macrūfí est ki hadd-i fāṣll-i Türkistān ve Îrān est. Türkistan ve İran'1 birbirinden ayıran büyük ve ünlü bir nehirdir.

Cîruft: Bi-kesr-i cîm ve żamm-i rā'-i mühmele belde'îst ez bilād-i Kirmān. Esreli cîm ve zammeli râ ile (Cîruft) Kirman beldelerinden biridir.

Cuci: Nām-ı püser-i Çengiz Han est ve Tuşi hem tacbîr mîşeved ve macnî-yi Cuci 'nāgāh bi-vücūd āmede' bāşed. Çün der carż-ı rāh nāgāh ez māder mütevellid şüd. Bidān sebeb ū rā Cuci nām nihādend. Cengiz Han'ın oğlunun adı, Tuşi de denir. Cuci sözü de 'aniden, beklenmedik şekilde ortaya çıkan' demektir. Çünkü annesi yoldayken aniden doğmuş ve o yüzden ona Cuci demişler.

Cumḳarag̉ul: Nām-ı yekî ez püserān-ı Hülagu Han est. Hülagü Han'ın oğullarından birinin adı.

Cuveyn: Bi-żamm-i evvel ve feth-i țānî nām-ı karye ve nāhiyetî est ez tevābic-i Horāsān. Horasan'a bağlı bir nahiye ve kasabanın adı.

Çaġatay: Nam-ı püser-i düvvüm-i Çengiz Han est ki bi-ḥükm-i Çengiz hükūmet-i Tūrān-zemîn rā dāş̧ ve Tūrān-zemîn cibāret'est ez mābeyn-i Karakorum ve Îran.Cengiz Han'ın ikinci oğlu; o Cengiz Han'ın buyruğuyla Turan yurdunun hükümdarı olmuştu. Turan yurdu da aslında Karakorum ile İran arasındaki bölgeden ibarettir.

çandavul: Cemacatî rā gūyend ki ez cakab-ı leşker bi-cehet-i muhāafazat mîāyend. Ordunun arka tarafını koruyan bir topluluk.

çatlağuç: Mîve-i diraht-ı saḳkız rā gūyend. Sakız ağacının meyvesine derler.

Çengîz Hुan: Der zebān-ı Tūrî bi-macnî-yi şāh-l şāhān est. Çünānki der în ebyāt șarîhan beyān fermāyed: Nihādîm nām-ı tü Çengîz Hān Ez in pes tü hod rā Temuçin meh̀vān. Ez an rū ki macnî-yi Çengîz Han Buved şāh-l şāhān-ı Tūrî-zebān. "Tûrî" dilinde 'padişahlar padişahı' anlamına gelir. Aşağıdaki dizelerde bu anlam açıkça beyan 
edilir: "Sana Cengiz Han adını verdik. Bundan sonra sen kendine Temuçin deme. Çünkü Cengiz Han sözü Tûrî dilinde padişahların padişahı demektir”.

Çer Olum: Nām-ı cū'î est der Türkistān ki Kaydu Han, cedd-i şeşüm-i Çengiz Han ez rūdhāne bîrūn āverde est. Cengiz Han'ın altıncı ceddinin nehirden çektiği akarsuyun adi.

çerik: Koşun ve casker-i nā-muntazam ve ġayr-ı müretteb rā gūyend. Düzensiz ve tertipsiz ordu ve askerler [topluluğuna] derler.

Çiçekan Bégi: Nām-l zevce-i Çengiz Huan est ez kabîle-i Oyrat. Cengiz Han'ın Oyrat kabilesinden olan zevcesinin adı.

çirge/çirga: Bi-macnî-yi șaf ve katạar est ve şikār-l çirge cibäret ez ān est ki vuhūş̧ ve hayvānāt-ı muhtelife rā ez cāhā-yı dūr șaf keşî̉e bi-yek mahall-i maclūm mîrānend ve der ān mahal ānhā rā ihātạa nümūde meşgūul-i şikār mişsevend. Siralanmışlık, katarlanmışlık anlamına gelir. Çirge avı vahşi ve vahşi olmayan hayvanları uzak yerlerden toparlayıp katarlayarak belli bir mekâna sürmek ve orada çevreleri kuşatılarak avlanmalarına denir.

Çohay: Nām-ı yekî ez püserān-ı Çengiz Han est. Cengiz Han'ın oğullarından birinin adi.

çök: Bā cîm-i Fārsî bi-macnî-yi zānū zeden ve taczû̀m kerden est. Diz çökmek ve saygı göstermek anlamına geliyor. ${ }^{25}$

\section{Bâb-ül-Hâ-ül-Mühmele}

hasşr: Cemācatî rā gūyend ki der dihāt bi-cihet-i kenden-i nehrî, yā besten-i seddî hemegî rā cemc mînümāyend. Köyde bir nehir kazıp açmak ya da bir bent kurmak için herkesin bir araya getirildiği topluluğa denir.

\section{Bâb-ül-Hâ-ül-Mucceme}

Hुāf: Nām-ı nāhiyetî est ez iḳlîm-i çihārum mensūb bi-Horāsān. Horasan'a bağlı dördüncü iklimin bir nahiyesinin adı.

Halac: Nām-l țāyfe'îst ez Etrāk. Türklerden bir taifenin adı.

25 Metinde Türkçe çök ve Farsça zeden'den oluşan bu birleşik fiil çök zeden şeklinde kullanıliyor ve birebir anlamı 'dizi yere vurmak'tır. 


\section{J()}

Han Balığ: Nām-ı kadîm-i şehr-i Pekin est ki Paçin hem güfte mîşeved. Pekin şehrinin eski adı, ona Paçin de denir.

Har-seng: Seng-i büzürg ve nā-hemvār rā gūyend ki der miyān-ı rāh mānic ez cubūr-ı merdüm bāşed. Yol üzerinde bulunan ve insanların geçişini engelleyen düzgün olmayan büyük bir kaya. ${ }^{26}$

Hutā: İsm-i şehrî̀st ez memālik-i Çin. Çin memleketlerinden bir şehrin adı.

hîk: Macrūf est yek hîk şerāb cibāret ez pencāh men şerāb est. Bir hîk şarap elli batman şaraba denk olarak bilinir. ${ }^{27}$

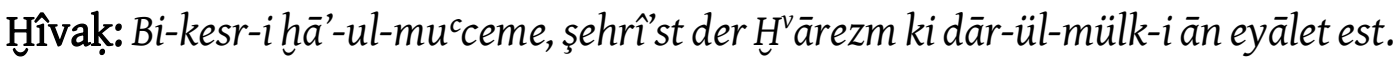
$H_{\imath}$ harfi kesre ile okunursa, Harezm'de bir şehir ve o eyaletin başkentidir.

Hocend: Bi-żamm-i evvel ve feth-i țānî ve sükūn-i nūn kașaba'î'st der māverāäünnehr ez iklìm-i pencüm. Birinci harfi zammeli, ikinci harfi fethall, nūn harfi de harkesiz olan [bu söz] Maveraünnehr'in beşinci ikliminden bir kasabanın adı.

Hoten: Nām-ı şehrîsst der Türkistān. Türkistan'da bir şehrin adı.

ḩª̄ce: Yacnî kedhüdā ve büzürg ve șāhib-i devlet ve nām-ı püser-i Güyük Han ibni Oktay Kaan est. Yani kethüda, büyük ve devlet sahibi ve Oktay Kaan'ın oğlu olan Güyük Han'ın oğlunun adı.

Hु̄ārezm: Memleket-i mucteberîst mābeyn-i Cürcān ve Deșt-i Kipçak ve Baḥr-i Hazer ve Buhārā ve dār-ül-mülk-i āncā kadîmen Ürgenc-i Köhne ve bacdhā Hî̀vak būde est ve ez şehrhā-yı muctebereş Hezār Esb ve Gürgānc est. Cürcan, Deşt-i Kıpçak, Bahri Hazer ve Buhara arasında muteber bir memleket ve oranın başkenti eskiden Köhne Ürgenc imiş, daha sonra da Hîvak olmuş. Hezâr Esb ve Gürganc [Harezm'in] muteber şehirleridirler.

\section{Bâbü'd-Dâl-ül-Mühmele}

Dabūl: Ber vezn-i șabūr, nām-ı mevżicî est der Sind. Sabûr vezninde Sind'de bir yerin adı.

26 Huar 'eşek' demektir, mecazî olarak büyük anlamına gelir.

${ }^{27}$ Hîkk Farsçada 'tulum' demek. 


\section{J(৫)}

Dakūḳ: Nām-ı şehrî est mābeyn-i Baġdād ve Erbîl. Bağdat ve Erbil arasında bulunan bir şehrin adı.

Debbūsîyye: Kaṣaba'î’st der șacîd-i Semerḳand. Semerkand'ın topraklarında bir kasaba.

Dervâze-i Fîrūzābād: İsm-i yekî ez dervāzehā-yı şehr-i Herāt est. Herat şehrinin giriş kapılarından birinin adı.

Deylem ve Deylemān: Bā evvel-i meksūr ve yā'-i mechūl ve lām-ı maẓmūm, nāmışehrî̀st ez vilāyet-i Gîlān. Lām harfi zammeli okunursa Gilân vilâyetinde bir şehrin adi. $^{28}$

\section{Bâbü'r-Râ-ül-Mühmele}

Rādkān: Nām-l şehrî est der Țūs ki marg̉zār ve çemen-i hūûi dāred. Tûs'ta çayır çimenli kırsal bölgesiyle ünlü bir şehrin adı.

Rekay: Nām-ı yekî ez birāderān-l Çengiz Han est. Cengiz Han'ın kardeşlerinden birinin adi.

Rukinse: Nām-ı zevce-i Hülagu püser-i Maskan bin Çaġatay est. Maskan bin Çağatay'ın oğlu Hülagu'nun zevcesinin adı.

Rüknî Zer: Rüknî mensūb bi-Rüknü'd-dîn est ki zer-i hāliș rā rāyic kerd. Rüknî, halis altını yaygınlaştıran Rükneddin ile bağlantılıdır.

\section{Bâbü'z-Zâ-ül-Mucceme}

Zāve: Ber vezn-i Sāve, nām-l şehrî est der Horāsān ki hālā bi-Hayderiyye meşhūr est. Sâve vezninde, Horasan'da şimdi Haydariye olarak bilinen bir şehrin adı.

Zernūḳ: Kaṣaba'îsst der kurb-ı Buhārā. Buhara'nın yakınında bir kasaba.

Zūzen: İsm-i vilāyet-i maçū̄î̀ est ez Horāsān. Horasan'ın çok bilinen bir vilâyetinin adı.

28 Metinde lâm'ın zammıla Deylum okunması gerektiği ve ikisinin de bir yer adı olduğu yazılı. Halbuki Deylem bugün İranîn kuzeyinde Buşihr vilâyetinin bir kazası, Deylemân ise Lâhîcân'ın bir köyünün adıdır. 


\section{J(৫)}

\section{Bâbü's-Sîn-ül-Mühmele}

Sabaçmut/ Sebçemūt (?): Nām-ı kabîle'îst ez Etrāk münteseb bi-Baharçin püser$i$ Kaydu Han. Kaydu Han'ın oğlu Baharçin'in mensup olduğu Türklerin bir kabilesinin ad.

Sebkü: Nām-l yekî ez birāderān-l Mengü Kaan est. Mengü Kaan'ın kardeșlerinden birinin adı.

Sebük Tigin: Lakab-i Sulțān Mahmūi Ġaznevî est ve macnî-yi ān mübārek-kadem est. Zîrā der lisān-ı Mogolî sebük bi-macnî-yi kadem ve tigin bi-macnî-yi meymūn ve mübārek est. Gazneli Sultan Mahmud'un lakabı ve [bu birleşik ad] 'adımı mübarek' anlamına gelir. Zira Moğol dilinde sebük 'kadem, adım', tigin de 'mübarek' demektir. ${ }^{29}$

Sedusan: Nām-ı şehrîst der Sind. Sind'de bir şehrin adı.

Selengay: Nām- nahiyetî est de memālik-i Hitay. Hitay memleketlerinde bir nahiyenin adı.

Sengun (?): Nām-ı püser-i Avung Han. Avung Han'ın oğlunun adı.

Sentan: Nām-ı yekî ez püserān-ı Cuci Han est. Cuci Han'ın oğullarının birinin adi.

Serîr: Nām-l vilāyetî est ki ġār-l Keyhüsrev der āncā est. Keyhüsrev'in mağarasının bulunduğu vilâyetin adı.

Serpul: Nām-ı kașaba'îst der nezdîkî-yi Semerkand. Semerkand'ın yakınında bir kasabanın adı. ${ }^{30}$

ser-şîr: Bi-macnî-yi yarlig ve fermān imtiyāz-ı mahșūṣ̂i est. 'Yarlığ ve ferman özel bir imtiyazdır' anlamına geliyor. ${ }^{31}$

Seyhūun: Nehr-i ma crūfí est der Māverā'ü'n-nehr. Maveraünnehr'de meşhur bir nehir.

Sıḳınak: Kașaba'îst ber kenār-ı Ceyḥūn. Ceyhun'un kıyısında bir kasabanın adı.

29 Eski Türkçede sepük 'donanıml, mücehhez', tigin de hem bir unvan hem de 'şehzade' anlamına gelir.

30 Farsçada 'köprü başı' anlamına gelen ser-i Pul'un kısalmış şekli olabilir. Farsçada 'işin başında, sorumlu' anlamina gelen ser-i kār da serkār olmuştur.

31 Ser-şîr < ser-i şîr Farsçada 'kaymak' anlamına geliyor. 


\section{J(৫)}

Sorḳutni Bégi: Nām-ı zevce-i Toli Han est ki vālide-i Mrngü Kaan bāşsed ve der baczî̀ nüsah-ı kadîme Sorḳktani Bégi nüvişte'end. Toli Han'ın zevcesinin ve Mengü Kaan'ın annesinin adı. Bazı eski yazma nüshalarında Sorḳuktai Bégi yazmışlar.

sovgat: Bi-macnî-yi cațiyye ve hediye ve tuhfe ve arnaġan. Bağış, hediye, armağan anlamına gelir.

soyurğal: İncām ve ihsān ve bahşşş-i dāimî rā gūyend. Daimî ödül ve bağış için kullanilır.

Sudak: Belde'̂̀sst der Deşt-i Kipçak vāḳı ${ }^{c} a$ der sāhil-i deryā ki bi-Halîc-i Kusțanțaniyye muttașl est. Deşt-i Kıpçak'da İstanbul Halici'ne bitişik olan denizin sahilinde bir beldedir.

suluḳ: çantay rā gūyend ki bi-lugiat-ı Tāzî̀ caybe est. Çanta için kullanılır ve ona Arapçada caybe (heybe) denir.

Tartak: Nam-ı püser-i Batu bin Cuci Han est. Batu bin Cuci Han'ın oğlunun adı.

Tintay Og்ul: Nām-ı birāder-i kūçikter-i Mengü Kaan. Mengü Kaan'ın küçük kardeşinin adı.

Tintay: Nām-ı yekî ez serdārān-ı mưteber-i Çengiz Han est. Cengizhan'ın güvendiği komutanlardan birinin adı.

Toyurgamış: Bi-macnî-yi incām ve iḥsān ve cātı̣fet est. İhsan, bağış ve merhamet anlamina gelir.

\section{Bâbü'ş-Şîn-ül-Mucceme}

Şādyāh̆: Muhaffef-i şādî kāhn est. Şāpūr bin Erdeşî şehr-i şādyāhn rā ez peder bi$h^{v} \bar{a} s t$ ve ù mużāyıka kerd. Bacd ez peder bi-harābî-yi ān emr fermūd ve pes ez harāb kerden der ān nokța şehr-i büzürgî binā nihād ve ān rā Nîşābūr nāmîd yacnî şehr-i Şāpūr ve ne bi-ma'nî-yi şehr est. ['Sevinç ve eğlence sarayı' anlamına gelen] şādî kāh̆'in kısalmış şeklidir. Erdişîr'in oğlu şâpûr bu şehri babasından istemiş. O da vermemiş. Babasından sonra o şehrin tahrip edilmesini emretmiş. O şehri yıktıktan sonra onun yerinde büyük bir şehir bina etmiş ve ona Nişabûr demiş yani Şapur'un şehri. Buradaki ne/nî ‘şehir' demek. ${ }^{32}$

\footnotetext{
32 Şehrin adı aslında Nişâpûr'dur. Nişâ, Hintçede 'gece' demek, pûr da bu dilde 'şehir' anlamına geliyor.
} 


\section{1)}

Şāhruhiyye: cibāret ez şehr-i Fenāket est. Fenâket şehrinin diğer adı.

Şāpūrhyāst: Nām-ı şehrî est mābeyn-i Bag̉dād ve Mülk-i Dey. Der eyyām-ı kadîm şehrî büzürg būde est meșhūr ve macrū fuve zikr-i ān der tevärîh mesțūr. Eknūn ez ān şehr cüz ism-i bîresm çî̀î bāḳ̂ nemānde est. Bağdat ve Mülk-i Dey arasında bulunan bir şehrin adı. Eski zamanlarda büyük ve meşhur bir şehir imiş. Tarihlerde kayda geçmiştir. Şimdi ise o şehirden resimsiz bir isimden başka bir şey kalmamış.

şāristān: Yacnî şehr ve şehristan est. Şehir ve büyük şehir demektir. ${ }^{33}$

Şehristān: Nām-l şehrî est der miyān-l Nişābūr ve Hưārezm. Nişabûr ve Harezm arasında bir şehirin adı.

şeker-deh/dih: Yacnîmerd-i çābuk ve celed ve ān ki der kārhā müheyyā ve āmade başed. Eli çabuk, becerikli ve her iş için hazırlıklı kişi demek.

Şiramun: Nām-ı püser-i Kucu bin Oktay Kaan est. Kucu bin Oktay Kaan'ın oğlunun adıdır.

şugūn: Bi-macnî-yi meymenet ve fäl-i hayr ve camel-i nîkū est. Uğur, meymenet ve hayırlı iş anlamına gelir. ${ }^{34}$

\section{Bâbü's-Ṣād-ül-Mühmele}

Șayın Huan: cibāret ez Batu bin Cuci Han bin Çengiz Han. Cuci Han bin Cengiz Han'ın oğlu Batu için kullanılan sözdür.

\section{Bâbü't-Ṭâ-ül-Mühmele}

Țālkān: Şehrîst mābeyn-i Belh ve Mervü'r-rūd der Māverā'ü'n-nehr vāklı ${ }^{c} a$ ber mevżici mürtefic mevsūm bi-Nukra Kūh. Maveraünnehr'de Belh ve Mervü'r-rûd arasında Nukra Kûh [anlamı Gümüş Dağı] denen yüksek bir mevkide bulunan bir şehirdir.

Țaraz: Şehrî est der Türkistān. Türkistan'da bir şehir.

Ṭayimgu: Nām-l şehrî est der iklîm-i Huta. Hita[y] ikliminde bir şehrin adı.

33 şehristān > şāristān.

34 Farsça bir sözdür ve شَّفون şeklinde yazılır. 
țoy: Bimacnî-yi cayş ü sürūr ü velîme ve mihmānî est. Dügüun, eğlence ve ziyafet anlamina gelir.

\section{Bâb-ül-Ġayn-ül-Mucceme}

Ġaymış Hvatun: Nām-ı zevce-i Güyük Han bin Oktay Kaan est ki māder-i Naḳud $H^{v} \bar{a} c e$ bcşed. Güyük Han bin Oktay Kaan'ın zevcesi; o da Nakud Hلvāee'nin annesidir.

Ġuz Balığ: Şehrî est der Türkistān ki ānrā Balasḳun gūyend. Türkistan'da Balasagun denen bir şehir.

Ġarcistān: Nām-ı vilāyetî est muttaṣıl bi-vilāyet-i Gūrr. Gūrr vilâyetine bitişik olan bir vilâyetin adı.

Guzz: Bi-żamm-i ġayn-ı mucceme ve teşdîd-i za'-i mucceme tā̄ife'î'st ez Türk. Gaynın zammeli ve [sondaki] zâ harfinin şeddeli okunmasıyla, bir Türk taifesi.

Ġazne ve Ġazneyn: Nām-ı vilāyet-i meşhūr est der Zābülistān. Zâbülistân'da Sultan Mahmut Gaznevî̀nin ve başkalarının başkenti olan ünlü şehrin adı.

Ġūr: Nām-ı vilāyetî est miyān-ı Horāsān nezdîk bi-Ġazneyn ve mensūb bi-Gūur rāa Gūûi gūyend ve Gürrîyān cemci ehālî-yi āncā est ve sengî rā hem ki bi-seng-i yarakāan macrū f est Ġūr gūyend. Horasan ve Garcistan'ın arasında olup Gazneyn'e de yakın olan bir vilâyetin adı. Gûr ile münasebeti olana Ġûrî, bu vilâyetin ahalisine de Gûrîyân derler. Seng-i yarakân (sarılk taşı) olarak bilinen taşa da güur denir. ${ }^{35}$

\section{Bâb-ül-Fâ}

Fenâket: Bi-feth-i fâ ve nûn ve tâ'-i fevkānîyye, şehrîst der Maverā'ü'n-nehr ez iklìm-i pencüm ve mucarrab-ı ān Benāket est. Çün Şāhruh bin Timur der ān tașarruf ve tacmîrî kerd, Şāhrutîyye nîz gūyend. Maveraünnehr'de beşinci iklimden bir şehirdir. Bu şehrin Arapça adı Benâket'tir. Timur'un oğlu Şahruh bu şehirde tamir ve düzenlemeler yaptığı için ona Şâhruhiyye de denir.

Ferḡāne: Şehrîst der Türkistān ez bilād-ı meşhūr-ı Maverā’ün-ner, țaraf-l şarḳ̂́y-eş Kāşğar, ġarbî-y-eş Semerkand, cenūbî-y-eş kūhistān-ı Bedehş̧ān, şimālî-y-eş Almalı̀ ve Yengi ki ānrā Utrār/Otrār gūyend. Maveraünnehr' in meşhur beldelerinden olan

35 Afganistan'da Gur şehri piyāle-i Gūur adlı çay kâsesi ile ünlüdür. İran'da da ilk defa bu şehirden gelen çaydanlığa ġūrî denir. Eskiden غورى şeklinde yazılan bu söz bugün Farsçada قورى olmuştur. İran'da ilk defa Buhara'dan gelen sobaya da buhārî̀ derler. 
Türkistan'da bir şehir, doğusunda Kaşgar, batısında Semerkand, güneyinde Bedahşan dağları, kuzeyinde de Almalıg ve Yengi var. Yengi'ye Taraz da denir.

\section{Bâb-ül-Ḳâf}

kaan: Bi-macnî-yi hakan ve pādişāh-ı ulū'l-emr est. Hakan ve buyruk sahibi padişah anlamına gelir.

Kadaḳ Noyın: Nām-ı yekî ez ser-kerdegān-ı mucteber-i Güyük Han est ki hall ü caḳd-ı umūr bi-dest-i ù būd. Güyük Han'ın güvendiği komutanlardan birinin adı. Güyük Han'ın memleketinin sorunlarını o çözümlüyordu.

Kadaḳaç: Nām-ı māder-i Şiramun bin Kücü bin Oktay Kaan bin Çengiz Han est. Şiramun bin Kücü bin Okaty Kaan bin Cengiz Han'in annesinin adı.

Ḳadġan: Nām-ı yekî ez püserān-ı Oktay Kaaan est. Oktay Kaan'ın oğullarından birinin adi.

kam: Bi-machî-yi fîlsū ${ }^{36}$ ve hakîm ve dānişmend est ve kāmān cem ${ }^{c}-i$ kām est ya ${ }^{c} n \hat{\imath}$ dānendigān-ı cilm-i nücūm ve kehānet. Filozof ve bilgin anlamına gelir ve bu sözün çokluğu kāmān'dır ve nücūm ilmini ve kehâneti bilenler demektir.

kanḳlı: Nām-ı kabîle'î'st ez Etrāk ki mesken-i ānhā der hudūd-ı Balasaḳun būde. Oturdukları yer Balasagun civarında olan Türklerin bir kabilesinin adı.

Ḳara Hülagü: Nām-ı püser-i Maskan bin Çaġatay est ki gāhî ez ū Karag̉ul ve gāhî Kara tacbîr mîşeved. Maskan bin Çağatay'ın oğlunun adı. Bazen ona Karag̉ul, bazen de Kara diyorlar.

Karag̉ul: Nām-ı püser-i Maskan bin Çaġatay est ki gāhî ez ū Kara Hülagu tacbîr mînümāyend. Maskan bin Çağatay'ın oğlunun adı, o bazen Kara Hülagü olarak da aniliyor.

ḳarakçıı: Bi-macnî-yi muhāâfiz ve pāsbān ve ḳaravul est. Koruyucu ve bekçi anlamina gelir.

Karakırım: Nām-ı vilāyetî est der Türkistān. Türkistan'da bir vilâyetin adı.

Karaköl: Memleketî est der Türkistān der țaraf-ı Buhārā. Türkistan'da, Buhara tarafında bir memleket.

36 Farsçada kullanılan şekli. 


\section{J(O)}

Karataş: Nām-ı mevżic'̂̀ est der nāhiyet-i Tenküt. Tenküt nahiyesinde bir yerin adı.

Karlığ ve Karliḳ: Ṭāfê̂̀sst ez țavāyif-i Etrāk ki hükm-rānhāa-yi Hîvak bidān mensūbend. Hîvak hükümdarlarının mensup olduğu Türk taifelerinden biri.

Karlığ: Nām-ı țāyfe'î’st ez Etrāk ki süknā-yı ānhā der hudūd-ı Balasakun būde est. İskān ettikleri yer Balasgun civarında olan Türklerin bir taifesinin adı.

Karlığān: Cemci $-i$ Karlı̀ est ki cibāret ez țāyfe-i mežkūre bāşed. Yukarıda anlatılan Karlig'ın çoğuludur.

ḳarşı: Yachî sarāy-ı hümāyūn ve karşıl-yı sūrî nām-ı sarāy-ı mahșūṣ est ki

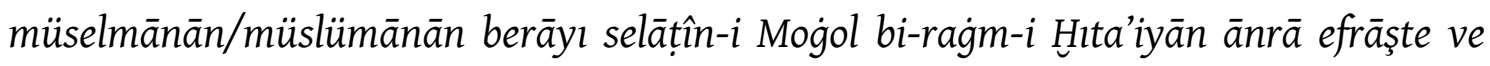
münakkaş kerde būdend. Yani uğurlu padişah sarayı ve karşı-yl sûrî de Müslümanların, Hıtaylılara rağmen Moğol sultanları için dikip süsledikleri özel saraydır.

Kayaş: Nām-l şehr ve nāhiyetî est der Türkistān. Türkistan'da bir şehir ve nahiyenin adı.

Kaydu Hुan: Nām-ı cedd-i şeşüm-i Çengiz Han est. Cengiz Han'ın altıncı ceddinin adı.

ḳımı: Gele ve llhı rā gūyend ve nev'î ez envāc-l şerāb ki ez şîr-i mādiyān tertîb dehend. Hayvan sürüsü ve yılkı demek; kısrak sütünden yapılan bir çeşit şarap.

Ḳırḳı: Nām-ı kalca'î’st der Türkiatan. Türkistan'da bir kalenin adı.

Ḳıyat: Nām-ı kabîle'î’st ez kabāyil-i Mog̉ol ki ābā' ve ecdād-ı Çengiz Han bi-în kabîle mensūbend. Cengiz Han'ın ecdadının mensup olduğu Moğol kabilelerinden bir kabilenin adı.

Ḳonḳurat: Kabîle-i mucteberîst ez kabāyil-i Mog̉ol. Moğolların çok bilinen bir kabilesi.

ḳopak: Nām-ı mahall-i ordu ve ikāmet-i kadîm-i Güyük Han bin Oktay Kaan est. Güyük Han bin Oktay Kaan'ın eskiden çadır kurup ikamet ettiği yer. 


\section{ग(৫)}

kopçur: Yachî mürācî-yi çihār-pāyān ez kabîl-i esb ve ester ve şütür ve gāv ve gūsfend. At ve katır ve deve ve sığır ve koyun gibi hayvanlara bakan demek. ${ }^{37}$

ḳorçı: Bi-macnî-yi cebe-dār ve silāh-dār est. Cephane ve silah sorumlusu anlamina gelir.

ḳoruğ: Bi-macnî-yi halvet ve mahallî rā ez dühūl ve hurū̄c-ı cumūmî memnū ${ }^{c}$ dāşten. Halvet demek, hem de bir yerin giriş çıkışını umûma yasaklama anlamına geliyor.

Kubila Ḳaan: İsm-i birāder-i Mengü Kaan est ki püser-i çihārum-ı Toli Han bin Çengîz Han bāşed. Toli Han bin Cengiz Han'in dördüncü oğlu olan Mengü Kaan'ın kardeşinin adı.

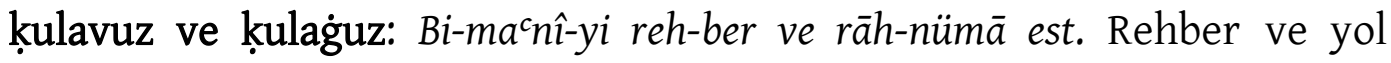
gösteren anlamina gelir.

Ḳupan: Türkistan'ın bir vilâyetinin adı. Cengizhan, memleketleri çocukları ve kardeşler arasında taksim ederken bu bölgeyi kendi veliahtı Oktay Kaan'a ayırd.

kupcur: At, katır, deve ve koyun gibi hayvanlara bakan kişi.

kuriltay: Yachî cemciyet ve ictimāa der meclisî bi-cihet-i müşāvere ve mașlahatendîşi der kārî. Bir konuda ya da bir iş için fikir alışverişi yapılması için bir mecliste toplanan topluluk anlamina gelir.

Kutġay: Nām-ı mevziî̀ est miyān-ı Karakorum ve Biş Balig. Karakorum ve Bişbalık adında bir yerin adı.

kutliğ: Bi-żamm-i kāaf bi-ma nhî-yi meymūn ve mübārek ve mukbil ve nîk-baht rā gūyend ve Kutlug Han ez cümle-i elkạb-ı Türkistān est. Mübarek, meymenetli ve mutlu anlamlarına gelir ve kutlig han Türkistan'da yaygın olan lakaplardandır.

\section{Bâb-ül-Kef}

genkāc: Bi-kesr-i evvel ve sükūn-ı țānî ve kāf-i Fārsî bi-machî-yi meşveret bāşed. Yacnî bi-cihet-i encām-ı kārî ve mühimmî șalah-endîşî nümāyend ve bi-feth-i evvel hem

37 Ferheng-i Fârsî'de kopçur Türkçe çevirisiyle şöyle açıklnıyor: Moğolca '1. Vergi, haraç; 2. Hayvanlara bağlanan vergi (ilhanlılar) (2633). Moğolca-Türkçe Sözlük'te de ġupçiğur 'vergi, haraç, baç' demek (Lessing, 2003/I: 579). 


\section{J(৫)}

āmede ve șahîh est. Meşveret demek, yani önemli bir işle ilgili danışma; gänkāc şeklide de kullanılır. ${ }^{38}$

Germîne: Şehrî est der nāhiyet-i Buhāāā. Buhara bölgesinde bir şehir.

gev: Bi-feth-i kậf-i Fārsî zemîn-i pest ve muġāk rā gūyend. Birinci harfin fetha ile okunmasıyla çökük ve çukur yere denir.

Gür Han: bi-macnî-yi hān-ı hānān est. Hanlar hanı anlamına gelir.

Güyük Han: Nām-ı püser-i Oktay Kaan est ki bacd ez peder salțanat ber ū mukarrer şüd. Oktay Kaan'ın oğlunun adı; Kaan'ın ölümünden sonra saltanat ona geçti.

Kāşġar: Şehrîst ez Türkistān mensūb bihūbān ve melîh-șūretān. Türkistan'da güzelleri ve güzel yüzlüleri ile ünlü bir şehir. ${ }^{39}$

Kebūdcāme: Bi- sükūn-l dāl-ı mühmele ism-i țāyfe'îsst ki der havāalî-yi Astarābād ve Gürgān tā nezdîk-i Hل̛̃ārezm süknā dāştend. Astarabad ve Gürgân havalisinden Harezm'e kadar uzanan bir alanda yaşamış olan bir halkın adı.

Kelār: Mevżicî est der nezdîkî-yi Kııpçak. Kıpçak yakınında bir yerin adı.

Kelken: Nām-ı yekî ez püserān-ı Çengiz Han est. Cengiz Han'ın oğularından birinin adl.

Kelrān (?): Nām-ı mevżi î est der yurt-ı aṣlî ve mahall-i tahtgāh-ı Çengiz Han būde est. Cengiz Han'ın esas yurdunun ve sarayının bulunduğu yerde bir mevki adı. ${ }^{40}$

Keş: Bi-feth-i evvel ve sükūn-i țānî nām-l şehrî’st der māverā'ü'n-nehr, nezdîk-i Nahşeb. Maveraünnehr'de Nahşseb'e yakın bir şehrin adı.

kevāşîr: bi-vezn-i tebāşî̀ muhaffef-i kūre-i Erdeşir est ki tahtgāh-ı Erdeşîr-i Bābekān būde, eknūn Kirmān ve arāzì-yi (Enșafahāat ?) est. Tebāşîr vezninde kūre-i Erdeşî̀' den kısalmadır. Erdeşîr Babekân'ın tahtgâhı buradaymış. Hâlen Kirmân ve Enșafahāt arazisindedir.

kotval: Yánî kal'a bégi. Kale beyi anlamina gelir.

38 Eski Türkçe keňeş’ten türeyen bu söz Farsçada kengāş şeklinde de kullanılır.

39 Ferheng-e Fârsî'de bu şehrin [ كاجغر = كاجغر = كاز غر ] gibi adları da var (1524).

40 Moğolistan'da Ulan Bator'un yakınında bir nehrın adı Keloran ya da Kerulen (Moin, 1381: 1594) 
Kök Saray: Nām-ı mevżiı̂ est der kurb-ı Semerkand. Semerkand'a yakın bir yerin adı.

köl: Ǵadîr ve mușanna ${ }^{c}$ rā gūyend. Su birikintisine ve yapılmış havuza denir.

Kucu: Nām-l yekî ez püserān-ı Oktay Kaan est. Oktay Kaan'ın oğullarından birinin adi.

Kutan: Nām-ı yekî ez püserān-ı Oktay Kaan bin Çengiz Han est. Oktay Kaan ibni Cengiz Han'ın oğullarından birinin adı.

Kuyay: Bi-lugat-ı Hita’îyān cibāret ez han-ı büzürg ve pādişāh est. Hita(y)lıların dilinde büyük han ve büyük padişah demek.

kuyung: Nām-ı zevce-i Gür Han ki sulțān-ı mülk-i Hıta büd. Haty'ın sultanı olan Gür Han'in zevcesinin adı.

\section{Bâb-ül-Lâm}

Lāhūr: Ez cümle-i şehrhā-yl meşhūr-ı Sind mîbāşed. Sind'in meşhur şehirlerinden biridir.

Lehānūr: Hemān şehr-i Lāhūr est. Bilinen Lâhûr'un başka bir adı.

Lehāver: Hemān şehr-i Lāhr est. Biline Lâhûr şehrinin başka bir adı.

\section{Bâb-ül-Mîm}

maylay: Yacnî mukaddeme ve țalî́a-i leşker. Ordunun ön tarafı, önkolu anlamina gelir. ${ }^{41}$

Maskan: Nām-ı püser-i Çag̉atay bin Çengiz han est. Çağatay bin Cengiz Han'ın oğlunun adı.

Māverā'ü'n-nehr: cibāret ez Tūrān-zemîn est, muhtevî-yi bilād ve bikāac ve nevāhî ve ribāc-ı bisyār, ammā hulāșa-i ān mesākin ve zübde-i ān emākin Buhārā ve Semerkand est. Turan yurdunu karşılayan bir addır. [Turan] çok nahiye, bölge ve memleketleri içine alır. Fakat o yerlerin en ilgi çekicileri Buhara ve Semerkand'da özetlenir.

Meken (?): Nām-l şehrîst. Bir şehrin adı.

\footnotetext{
${ }^{41}$ Maylay, Moğocada ve Türkmencede ‘alın' demek.
} 
Melik Oġul: Nām-ı püser-i Maskan bin Çagaatay est. Maska bin Çağatay'ın oğlunun adı.

Minzi: İsm-i nāhiyetî est der akșā-yı Hitay. Hitay'ın ücra bir yerinde bir nahiyenin adi.

Moġol: Așleş Moňgul est, mütederricen bi-tahrîf ve tahfif Mog்l güfte şüd. İsm-i kavm-i mucazzamî est der Tataristān müştemil ber kabāyil ve țavāyif-i kețîre ve der kadîm-ül-eyyām tābic ve muț'icici Çin būde'end. Bacdhā salțanat ve hü̈uūmet-i müstakille peydā nümūde bi Hل̄ârezm ve Îrān-zemîn müstevlî şüdend. Bu söz aslında moňğul'dur, tedricen tahrîf ve tahfîfe uğrayarak Mog̉ol olmuştur. Bunlar Tataristan'da büyük bir kavimdir ve çok sayıda kavim ve kabileleri vardır. Bu halk eskiden Çin hükümdarlarına tabi idiler ve daha sonra müstakil saltanat ve hükümdarlıkları olmuş ve Harezm ve İran'ı istilâ etmişler.

Muka Hु̄ātūn: Nām-ı yekî ez zevcāt-ı Oktay Kaan est. Oktay Kaan'ın zevcelerinden birinin adı.

Muka: Nām-ı yekî ez birāderān-ı Mengü Kaan est. Mengü Kaan'ın kardeşlerinden birinin adı.

Multan: Ez vilāyāt-ı Sind est Miyān-ı Kandahār ve Lāhūr. Kandahar ile Lahur arasında bulunan Sind vilâyetlerindendir.

Mükrān: Bi-żamm-i evvedl, vilāyetî est ez iḳlìm-i düvvüm miyān-ı Kirmān ve Sîstān. Birinci harfin zammıyla, Kirmân ve Sîstan arasında ikinci iklimden bir vilâyet.

\section{Bâbü'n-Nûn}

Nag̉u ve Naḳu: Bā ġayn-i mucceme ve kaf-ı karaşet nām-ı püser-i Güyük Han bin Oktay Kaan est. Güyük Han ibn-i Oktay Kaan'ın oğlunun adı.

Nahşseb: Ber vezn-i mațleb/mațlab şehrî est macrū der Māverā'ü'n-nehr, ez āncā tā şehr-i Keş dü rūze rāh bāşed. Mațleb/mațlab vezninde, Maveraünnehr'in meşhur şehri, oradan Keş şehrine iki günlük yoldur.

Namking: Şehrîst der memleket-i Hıtay. Hitay memleketinde bir şehrin ad ${ }^{42}$

${ }^{42}$ Bugün Çin'de Nanking ya da Nanjing denen şehri anımsatıyor. 
nāyje: Bi-kesr-i țâliț ve feth-i zā-yi Fārsîlūle-i ibrîk ve emtāal-i ānrā gūyend. İbriğin su akıtan borusu ve ona benzer şeyler anlamına gelir.

Nayman ${ }^{43}$ : Nām-l kabîle'̂̀'st ez Tatar ki bā țāyfe-yi Özbek muhțelit şüde ve mesken$i$ ānhā der miyān-ı Semerkand ve Buhāāā est. Semerkand ve Buhara arasında iskân eden ve Özbeklerle karışan bir Tatar kabilesi.

nerke: Yacnî șaf ve cerge ve devr giriften ve halka sāhten est. Sira ve topluluğun daire şeklinde durması anlamına gelir. ${ }^{44}$

neva: Bi-macnî-yi girevgān est ve çendîn macnî-yi dîger hem dāred. Rehin anlamına gelir, başka da birkaç anlamı var.

nev-ker: Muhaffef-i nev-kār est, yacnî şerîk ve mu'āven der tedbîr ve ıșlāh-l umūr. Nev-kār'ın kısaltılmışs şekli ve ortamı düzenlemek için ortak ya da yardımcı olan. ${ }^{45}$

Novkāān: Nām-l yekî ez şehrhā-yl Ṭūs est. [İran'da] Tûs bölgesinin şehirlerinden birinin adı. ${ }^{46}$

Nukra Kūh: İsm-i mevżicî est ki şehr-i Ṭālkān der ān vākịi est mābeyn-i Belh ve Mervürr-rūd. Belh ile Mervü'r-rûd arasında, Talkan şehrinin bulunduğu bölgenin $\operatorname{ad}_{1 .}{ }^{47}$

Nūr: Kașaba'î’st der nezdîkî-yi Buhārāā. Buhara'ya yakın bir kasabanın adı.

nuzl/nüzl: Bi-żamm-i nūn tedārükîst kabl ez resîden-i mihmān āmāde mîdārend. Misafir gelmeden önce görülen hazırlık. ${ }^{48}$

${ }^{43}$ yâ harfinin üstünde yanlışlıkla bir ötre konmuş.

${ }^{44}$ Ferhng-e Fârsîbu sözün Türkçe olduğunu yazıyor ve 'bir şeyin etrafına konan halka' anlamına geldiğini bildiriyor. Diğer anlamını da Türkçe çevirisiyle şöyle açıklıyor: 'Av hayvanlarının belli bir alanın dışına çıkmaması ve padişâh ve emîlerin kolayca avlanabilmesi için bir insan kalabalığının o alanın etrafını çevirmesi. Buna cerge de denir'.

45 Bu söz Moğolca kökenli olarak bilinir. Moğolca 'dost, arkadaş, yoldaş’ anlamına gelen nökür/nöxör (Lessing, 2003/II: 927), Türkçede ve Farsçada nöker şeklinde 'hizmetkâr' anlamında kullanılır.

46 Farsçada bu şehrin adı نو غوان şeklinde yazıllyor ve Nowġān şeklinde telaffuz ediliyor. Osmanlıca telaffuzu Nevġān olurdu.

47 Nukra'nın bir anlamı 'gümüş', Nukra Kūh da 'Gümüş Dağı' demek.

48 Arapça nüzūl'ün kökü. 


\section{J(ఠ)}

\section{Bâb-ül-Vâv}

Vahş: Nām-ı şehrî̀st der Māverā'ü’n-nehr. Maveraünnehr'de bir şehirdir.

\section{Bâb-ül-Hâ'}

Herdu: Nām-ı yekî ez püserān-ı Cuci Han est. Cuci Han'ın oğullarından birinin adi.

Hezār Esb: Ez şehrhāa-yı mucteber-i memleket-i $H^{v}$ ārezm est ve Hezār Esf nâz güfte mîşeved. Harezm memleketinin muteber şehirlerinden biridir. Ona Hezâr Esf de deniyor. ${ }^{49}$

Hülagu: Nām-ı birāder-i Mengü Kaan est ki hü̈kūmet-i Îrān-zemîn bi-̄̄ tefvî̀ şüd. Kendisine İran hükümdarlığı verilen Hülagu, Mengü Kaan'ın kardeşinin adıdır.

\section{Bâb-üll-Yâ}

yalavac: Așleş yolavuc est. Bi-tahrîf ve tahfif yalavac hem güfte mîşeved ve macnîyi ān reh-nümā ve reh-ber ve delîl ve mürşid ve resūl ve peyǵaber est. Bu sözün asl1 yolavuç'tur, tahrif edilmiş şekli de yalavaç'tır. Bu sözün anlamı da rehber, kılavuz, resul ve peygamberdir.

yām: Menzil-i bārgîrî mānend-i çapar-ḩāne. Çapar-hane, eski posta sisteminde yük alma ve durak yeri.

yarg̉u: Bi-macnî-yi mușādere ve mu'āhaže ve istințāk est. Musâdere, muâhaze ve istintâk anlamına gelir.

yarg்uç: Manșibî est ki hậāa $\bar{u}$ rā emîr-i dîvān gūyend. Yacn'i güneh-kārān rā sühan-purs u siyāset-resān. Şimdi emîr-i dîvân denen bir makamdır. Onlar suçluları sorgular ve cezalandırırlar.

yarlığ: Yacnî menşūr ve fermān-ı pādişāhān. Padişahların fermanı ve tezkereleri demektir.

yasa ve yasaḳ: cỉbāret ez kāānun-nāme-i mütecallika ber siyāset-i medeniyye ve nazm-ı memleketî est. Medenî siyaset ve memleketin düzeniyle ilgili "kanunnâme".

49 Farsçada bu ad 'bin at' anlamına gelir. 


\section{ग(৫)}

yasamişî: Yacnî hükūmet ve hükümrānî ve nazm ve tertîb dāden. Hükümet ve hükümdarlık ve düzeni temin etmek anlamına gelir.

yāy: İsticmāl-i hacer-ül-mațar rā gūyend. Yacnî cibāret ez camelî est ki bi-icmāl-i ān bārān mîbāred. Kullanıldığı zaman yağmur yağdırdığına inanılan hacer-ulmatar'da yararlanilmas1. ${ }^{50}$

Yemme Noyan: Nām-ı yekî ez ser[kerde]gān) ve noyanān-ı mucteber-i Çengiz Han. Cengiz Han'ın tanınmış önderlerinden ve noyanlarından birinin adı.

Yeni: Hemān şehr-i Almalig est ki Taraz hem güfte mîşeved. Almalıg şehrinin bilinen başka bir adı; ona Taraz da denir.

Yeslun Hुvatun: Nām-ı zevce-i büzürgter-i Çaġatay bin Çengiz Han. Çağatay bin Cengiz Han'ın büyük zevcesinin adı.

Yesun Çin Bégi: Nām-ı māder-i Cuci Han ve Çaġatay ve Oktay Kaan ve Toli Han est. Cuci Han, Çağatay, Oktay Kaan ve Toli Han'ın annesinin adı.

yezek: Bi-feth-i evvel ve țānîve sükūn-i kāf cemc-i kalîlve merdüm-i kemî rā gtyend ki pîşāpişs-i leşker mîrevend mānend-i karavul ve pāsbān ve cāsūs. Ordunun önünden giden bekçi, koruyucu ve casus görevlerini yerine getiren küçük bir kalabalık. ${ }^{51}$

Yisu Buḳa: Nām-l püser-i Maskan bin Çagaatay est ve gāhî ez ū Yisu Buġa Og்ul hem tacbîr mîşeved. Maskan bin Çağatay'ın oğlunun adı, bazen ona Yisu Buġa Og̉ul da deniyor..$^{52}$

Yisu: Nām-l püser-i Çaġatay bin Çengiz Han est ve gāhî ez ū Yisu Mengü hem tacbîr mîşeved. Çağatay bin Cengiz Han'ın oğlunun adı, ona bazen Yisu Mengü de deniyor.

Yoşmut: Nām-ı yekî ez püserān-ı Hülagu Han est. Hülagu Han'ın oğullarından birinin ad.

yurt: Mahall-i ikâmet rā gūyend. İkamet edilen yer demek. ${ }^{53}$

50 Burada geçen ḥacer-ül- matar 'yağmur taşı' demek.

51 Bu söz Farsçadır.

52 Buġa, Türkiye Türkçedesinda boğa olmuştur.

53 Sözlüğün sonunda yazma sahibinin mührü vardır ve Kitābhāne-i Cacfer Sulțān El-karānî Tebriz 1365 (Hicrî Kamerî) yazılıdır. Bu tarihte Farsçada albaylara sultan deniyordu. Bu, Osmanlı sultanlarıyla alay etmek 


\section{J(e)}

\section{Kaynakça}

Atalay, B. (1998). Divanü Lugat-it-Türk Tercümesi I-IV. Türk Dil Kurumu Yayınları.

Aydinlu, S. (1396). Negâhî be Vâjehâ-ye Torkî-ye Şâhname-ye Ferdowsî [Firdevsi'nin Şâhnamesinde Türkçe Kelimelere Bir Bakış]. Metn-Şenâsî-ye Edeb-e Fârsî, 12(2), 11-36.

Azmun, Y. (2007). Burhan-1 Katı (Katı Burhan). Türk Dili ve Edebiyatı Araştırmaları Dergisi, 13(1), 35-46.

Azmun, Y. (2016). Söz Kökümiz Öz Kökümiz. Gün Neşiryatı.

Caferî, S. \& Âlîzâde, M. (1399 H. Ş.). Tahlîl-e Sâhtârî ve Macnâî-ye Berhîi Aclâm-e Torkî-ye Târîh-e Cihân-güşâ-ye Cuveynî [Cüveynî̀nin Târîh-i Cihân-güşâ'sında Bazı Türkçe Terimlerin Yapısal ve Semantik Analizi]. Metn-Şen'asî-ye Edeb-e Farsî, 12(2), 113-127.

Clauson, S. G. (1972). An Etymological Dictionary of Pre-Thirteenth-CenturyTurkish. Oxford University Press.

Doerfer, G. (1963). Türkische und Mongolische Elemente im Neupersischen, unter Besonderer Berücksichtigung älterer neupersischer Geschichtsquellen, vor allem der Mongolen- und Timuriszeit I. Franz Steiner Verlag.

Ercilasun, A. B. (2020). Atâ Melik Cüveynî Neler Gördü, Neler Duydu? Türk Dili, 822, 4-9.

Eren, H. (1999). Türk Dilinin Etimolojik Sözlüğü. Ankara.

Erşâdîfer, A. (1379). Ferheng-e Vajgân-e Torkî der Zebân ve Edebiyât-e Fârsî [Fars Dili ve Edebiyatında Türkçe Sözlerin Sözlüğü]. Bâğ-e Endîşe.

Ethé, H. (1351). Târîh-e Edebiyât-e Fârsî. Farsçaya Çev. Şafak, R. Emîr Kebîr.

Hâtemî, A. (1373). Şerh-e Moşkelât-e Târîh-e Cihân-güşâ-yı Cuveynî [Cüveynî’nin Târîh-i Cihân-güşâ’sının Zorluklarının Açılanması]. Baba.

Houtsma, A. (1894). Ein türkisch-arabisches Glossar. E.J. Brill.

Kazvînî, M. (2008). Târîh-i Cihân-güşâa-yı Cüveynî. Hermes.

Koçoğlu, T. \& Ahmadoughli, A. (2020). Cüveynî̀nin Târîh-i Cihân-güşâsı'ndaki Bazı Türkçe-Moğolca Kelimeleri Açılayan Bir Lügatçe. KARE, 9, 91-132.

Lessing, F. D. (2003). Moğolca-Türkçe Sözlük I-II. Çev. Karaağaç, G. Türk Dil Kurumu Yayınları.

Moin, M. (1381). Ferheng-e Fârsî. Emîr Kebîr.

için Safevîler döneminde çıkarılan bir unvan. Buna karşılık, Osmanlılar da generale padişahın kısalmış şekli olan Paşa demişler. Buna göre, Cafer Sultan, albay rütbeli bir subay olabilir. 


\section{Je)}

Mûsevî, M., (1384). Vâjgân-e Torkî ve Moğolî-ye Târîh-e Cihân-güşâ-ye Cuveynî [Târîh-i Cihân-güşâ'da Türkçe ve Moğolca Sözler]. Âyîne-ye Mîrâs, 30-31, 59-89.

Nâînî, M. S. (1380). Vajgân-e Torkî der Zebân-e Fârsî [Farsçada Türkçe Sözler]. Peyâm.

Öztürk, M. (1998). Târîh-i Cihân-Güşâ. Kültür Bakanlığı Yayınları.

Rezâyî, M. (1398). Ertebât-e Zebânhâ-ye Torkî, Moğolî, Huatâ der Teşhîs-e Vâjehâ-ye Dahîle Torkî ve Moğolî der Zebân-e Fârsî [Türk, Moğol ve Hitay Dillerinin Fars Dilindeki Türkçe ve Moğolca Sözlerle İlişkisi]. Zebân-Pejûhî-ye Daneşgâh-e El-Zehrâ, 11(36), 7-20.

Şeyh Süleyman Efendi (1298). Lugat-i Çağatay ve Türkî-yi Osmânî. Mihrân.

Türkiye'de Halk Ağzından Derleme Sözlüğ̈̈ I-XII (1993). II. Baskı. Türk Dil Kurumu Yayınları.

XIII. Yüzyıldan Beri Türkiye Türkçesiyle Yazılmış Kitaplardan Toplanan Tanıklarıyla Tarama Sözlüğü (1996). 8 Cilt. II. Baskı. Türk Dil Kurumu Yayınları. 